\title{
Is Pepsi Really a Substitute for Coke? Market Definition in Antitrust and IP
}

\author{
Mark A. Lemley \& Mark P. McKennA*
}

TABle OF CONTENTS

I. Market Definition in IP Doctrine . . . . . . . . . . . . . . . . . 2059

A. TRADEMARK ......................... 2060

1. Functionality .................. 2060

2. Genericness ..................... 2066

B. PATENT ............................. 2069

1. Damages ........................ 2070

2. Nonobviousness . . . . . . . . . . . . . . . 2071

C. COPYRIGHT . . . . . . . . . . . . . . . . . . . 2072

1. Distinguishing Ideas from Expression . . . . . . . . 2072

2. Fair Use and Market Harm . . . . . . . . . . . . 2074

D. THE PROBLEM WITH IMPLICIT MARKET DEFINITION . . . . . . . 2075

II. Market Definition and Product Differentiation . . . . . . . . . 2077

A. MARKET DEFINITION IN ANTITRUST LAW . . . . . . . . . . . . . 2077

B. THE ROLE OF IP RIGHTS IN DEFINING MARKETS . . . . . . . . . . . 2080

C. IMPLICATIONS OF MARKET DEFINITION IN IP CASES . . . . . . . . 2091

III. Rethinking Market Definition in Antitrust . . . . . . . . . . . . . . 2094

A. IS ANTITRUST MiSCALCULATING MARKETS IN IP CASES? . . . . . . 2094

B. IS MARKET DEFINITION ITSELF A FLAWED ENTERPRISE? . . . . . . . 2097

* Mark A. Lemley is the William H. Neukom Professor, Stanford Law School and partner, Durie Tangri LLP. Mark P. McKenna is Professor of Law and Notre Dame Presidential Fellow, Notre Dame Law School. (C) 2012, Mark A. Lemley \& Mark P. McKenna. Thanks to Joe Bauer, Tim Bresnahan, Julie Cohen, Deven Desai, Liran Einav, Rich Gilbert, Eric Goldman, Rose Hagan, Herb Hovenkamp, Louis Kaplow, Dan Kelly, Christopher Leslie, David McGowan, Roger Noll, Michael Risch, Maurice Stucke, Avishalom Tor, and participants in the IP Scholars' Conference and workshops at Stanford Law School, Cornell Law School, Notre Dame Law School, and Georgetown University Law Center for helpful comments, and to Catherine Mitros for research assistance. 


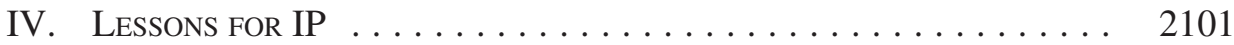

A. COPYRIGHT ........................ 2104

1. Substantial Similarity and the Derivative Work Right . . 2104

2. Fair Use . . . . . . . . . . . . . . . . . . . . . . . . . 2107

B. TRADEMARK .......................... 2108

1. Mark Similarity .......................... 2108

2. Sponsorship or Affiliation Confusion and Dilution .... . 2109

3. Comparative and Keyword Advertising ........... 2111

C. THE SCOPE OF PATENT RIGHTS . . . . . . . . . . . . . . . . . 2112

D. EXPERIMENTAL USE AND REVERSE ENGINEERING _........ 2114

E. EXHAUSTION AND THE FIRST SALE DOCTRINE $\ldots \ldots \ldots \ldots \ldots \ldots .2115$

Conclusion . . . . . . . . . . . . . . . . . . . . . . . . . . . . . . . . 2117

Does Pepsi compete with Coke? It seems a straightforward question; perhaps you think it has a straightforward answer. Sure they compete, you might say; they are both colas, they are used for the same purpose, they are sold next to each other in the grocery store, and they cost about the same. ${ }^{1}$ In fact, however, the answer is far from clear. Whether you think Coke competes with Pepsi may depend on whether you drink one of them. If you do, ask yourself this question: how big a price increase would it take before you would switch from one to the other? A penny? Five cents? Ten cents? What if the price doubled? Maybe you wouldn't switch at any price. ${ }^{2}$ If you are like a significant number of consumers, it would take a pretty dramatic change in price to get you to give up your preferred brand.

For antitrust, this insensitivity to price has a simple-and shockingimplication: Coke and Pepsi don't compete in the same market. Antitrust defines markets by asking, in part, whether a small but significant nontransitory increase in price (or SSNIP) above marginal cost would cause customers to switch from one good to another. And by small, the regulators mean something like $5 \%{ }^{3}$ So if a bottle of Coke costs $\$ 1.60$, unless a price increase of eight

1. A recent price check showed a six-pack of Coke selling for $\$ 4.19$ (69.8 cents/can) and a six-pack of Pepsi selling for $\$ 3.99$ (66.5 cents/can), a 5.0\% price differential. Priced at Draeger's Supermarket, Los Altos, Cal. (Feb. 25, 2012).

2. If you think this, you're kidding yourself. You wouldn't pay $\$ 1$ million for a can of Coke, right? But a slightly modified form of the statement in text - that a particular customer wouldn't switch at any likely price to an alternative beverage-accurately describes some customers. See infra note 139 and accompanying text.

3. U.S. Dep't of Justice \& Fed. Trade Comm'n Horizontal Merger Guidelines, 57 Fed. Reg. 41,552 (Sept. 10, 1992) [hereinafter 1992 Guidelines]. 
cents would send so many consumers running to buy Pepsi that Coke would lose money, the two don't compete. And while supply substitution can also constrain market power, that won't work here either; Pepsi-Cola can't (legally) start making Coke rather than Pepsi just because the price went up. By our classic antitrust definition, then, Coke and Pepsi are not in the same market. ${ }^{4}$ And assuming Coke's price change doesn't send customers off to any other drink either, then Coke is in a market by itself, one in which it has market power.

Nor is this an isolated result. In market after market, intellectual property (IP)-based product differentiation and brand loyalty mean that small price changes have little or no effect on purchasing behavior. Customers who want a Harry Potter novel won't be satisfied with a somewhat cheaper Stephen King novel. New York Yankees fans won't accept a Boston Red Sox hat instead of one supporting their team. And, perhaps most remarkably, brand-loyal drug customers will happily choose Advil $^{5}$ even though a substitute guaranteed by the Food and Drug Adminstration (FDA) to be functionally identical ${ }^{6}$ is sitting right next to it on the drugstore shelf at as little as half the price. ${ }^{7}$ To antitrust law, all these products have market power in their own, individualized markets.

If we took market definition seriously, antitrust law would look very different as applied to IP. Monopolists are subject to a variety of constraints that ordinary competitors don't face. To take just one example, exclusive dealing arrangements are subject to the rule of reason: they are unlawful if they foreclose a substantial share of the market. ${ }^{8}$ If any well-known brand has power in its own, individually defined market, exclusive deals or licenses signed by those brands would probably be illegal. That result would require a major change in business practice.

4. But see PepsiCo, Inc. v. Coca-Cola Co., 315 F.3d 101, 106-07 (2d Cir. 2002) (per curiam), where the court found that fountain-dispensed soft drinks were the relevant market and consequently treated the two companies as competitors.

5. Jura Liaukonyte, Is Comparative Advertising an Active Ingredient in the Pain Relief Market? 10-11 \& tbl.1 (May 9, 2011) (conference paper), available at http://faculty.chicagobooth.edu/workshops/ marketing/archive/pdf/liaukonyte.pdf (showing that brand name Advil had a $16.79 \%$ share of the over-the-counter pain relief (analgesics) market, almost a two-to-one advantage over generic ibuprofen, which had a $9.28 \%$ share).

6. Generic Drugs: Questions and Answers, FoOD \& DRUG AdmIn., http://www.fda.gov/Drugs/Resources ForYou/Consumers/QuestionsAnswers/ucm100100.htm (last updated Aug. 24, 2011) ("A generic drug is identical - or bioequivalent - to a brand name drug in dosage form, safety, strength, route of administration, quality, performance characteristics and intended use.").

7. See, e.g., Consumer Reports Health Best Buy Drugs, The Nonsteroidal Anti-Inflammatory Drugs: Treating Osteoarthritis and Pain, Comparing Drug Effectiveness, Safety, and Price 12 (2011), available at http://www.consumerreports.org/health/resources/pdf/best-buy-drugs/Nsaids2.pdf (showing a $40 \%$ price difference between a month's supply of Advil $200 \mathrm{mg}$ tablets and the generic equivalent).

8. See, e.g., Tampa Elec. Co. v. Nashville Coal Co., 365 U.S. 320, 327 (1961) (“[A]n exclusive dealing arrangement ... does not violate [antitrust law] unless the court believes it probable that performance of the contract will foreclose competition in a substantial share of the line of commerce affected."). 
IP law also depends to some extent on market definition. A variety of IP doctrines also require courts to define markets, though they often do so in a more ad hoc way than does antitrust. Here too, actual practice seems at odds with what antitrust's approach to market definition requires. If generic drugs don't compete with their branded counterparts, then it makes little sense to award damages in patent cases on the assumption that sales of the infringing product cause the patentee to lose sales. If the shape of a handbag distinguishes it from all other handbags and therefore defines a distinct market, that design should be deemed functional and hence unprotectable under trademark law. And if counterfeit goods don't substitute for authentic goods in the minds of consumers, the case for awarding the trademark owner lost profits from those counterfeits seems dubious at best. In short, a world that recognized the market power apparently conferred by IP rights would impose many more restrictions on IP owners than our cases do today, as a matter both of antitrust doctrine and IP law. And, we would be a lot more worried about the anticompetitive effects of IP rights generally. The IP-antitrust relationship would look a lot more like a persistent conflict, and antitrust would limit IP rights more than it currently does.

Perhaps the problem is not with the substantive application of antitrust and IP law but with market definition. Antitrust market definition has arguably become too ossified, dependent on assumptions about competition that are static and presuppose homogeneous products that compete solely on price and quality. This may be why courts have not been able to figure out how to define markets appropriately in the many IP settings where market definition is required: they don't really know what it means for IP products to compete. Led by Louis Kaplow, a number of scholars have challenged the primacy of traditional market definition rules as unsuited to a complex world with differentiated products and heterogeneous preferences. ${ }^{9}$ In the 2010 merger guidelines, the United States Department of Justice and Federal Trade Commission took a substantial step away from reliance on formulas to establish market definition and market power, focusing instead on more direct evidence of competitive effects of mergers, such as higher prices and reduced innovation. ${ }^{10}$ We think this was a step in the right direction. Both antitrust and IP need tools for market analysis that account for the dynamic nature of innovation and the differentiated nature of IP products. So perhaps courts in IP cases are right when they ignore antitrust's traditional approach to market definition, even if they haven't been doing so consciously.

9. Louis Kaplow, Market Share Thresholds: On the Conflation of Empirical Assessments and Legal Policy Judgments, 7 J. Competition L. \& Econ. 243, 252-58 (2011) [hereinafter Kaplow, Market Share]; Louis Kaplow, Why (Ever) Define Markets?, 124 HaRv. L. Rev. 437, 440 (2010) [hereinafter Kaplow, Why (Ever)].

10. U.S. Dep't of Justice \& Fed. Trade Comm'n., Horizontal Merger Guidelines (2010) [hereinafter 2010 Guidelines], available at http://www.justice.gov/atr/public/guidelines/hmg-2010.pdf. 
In fact, we think the answer lies somewhere in between the two extremes. Antitrust law must recognize that the general point of IP rights is to create some form of differentiation and, therefore, some (usually constrained) power over price. Treating any product that does so as a monopoly can be counterproductive, both because it will put antitrust law into regular conflict with IP policy and because it may discourage interbrand competition more than it promotes intrabrand competition. At the same time, both IP and antitrust law are wrong to ignore the implications of product differentiation and the power it gives IP owners over customers who strongly prefer one brand or type of product. ${ }^{11}$ The law needs to acknowledge that power in setting IP policies, in awarding remedies, and in evaluating the competitive effects of IP licensing. And both IP and antitrust law need to focus less on artificial market boundaries and more on the actual effects of IP rules and IP owner conduct.

In Part I, we consider the various circumstances in which the IP laws define markets, implicitly or explicitly, and the assumptions the IP laws make about market power. In Part II, we discuss the differentiated nature of IP markets from an antitrust perspective and the surprising ways traditional market definition would treat those markets. In Part III, we explore the limits of the market definition principle in both IP and antitrust and offer some initial thoughts as to how the law might steer a middle ground between finding market power in every IP case and ignoring the evidence of market segmentation. Specifically, we argue that courts need to stop conceiving of market power in binary terms when it is better seen as a question of degree: whether and how much market power an IP right enables depends on the number and quality of available substitutes for the products or services covered by the IP right. Moreover, courts need to recognize that, although consumers' willingness to switch to an alternative may sometimes be determined by functional similarity, that is often not the case for goods covered by IP rights. That certain IP rules create greater market segmentation means that, if excessive product differentiation is a concern, some doctrines are better suited than others to address that issue. We conclude in Part IV by identifying the doctrines in IP law that most contribute to market segmentation and therefore provide the best policy levers to modulate that segmentation.

\section{Market Definition In IP Doctrine}

A wide variety of IP doctrines require courts to engage, explicitly or implicitly, in market definition, or at least something that closely resembles it. Courts

11. As we explain below, there has been remarkable cognitive dissonance among courts and scholars alike on this point. On the one hand, advocates of IP rights emphasize the need for strong rights to create incentives, which can only be created if the rights in fact effectively enable commercially valuable differentiation. On the other hand, however, when confronted with the costs of such protection, many of these same advocates insist that IP rights create no power because functional substitutes are readily available. See infra section II.B. 
can't, for example, determine whether exclusive use of a product feature puts competitors at a "significant non-reputation-related disadvantage" 12 such that the feature is functional; determine market harm in copyright; or determine the amount of profit a patentee lost because of an infringement, without engaging in market definition. Yet, despite the widespread reliance on market definition in IP, courts have developed no apparent methodology for defining markets. Indeed, courts frequently don't even acknowledge that they are drawing difficult lines between markets. This isn't particularly surprising given how little attention market definition has received in the IP literature. It is, however, a problem.

In this Part, we describe several contexts in which market definition matters in IP cases. We do not suggest this is an exhaustive list, only that these are important contexts where market definition is necessary and often outcomedeterminative. And as we describe, courts make these important decisions entirely by their own intuitions. This is a problem, we argue, that both reflects dissonance about the costs and benefits of IP protection and enables parties to act strategically.

\section{A. TRADEMARK}

Courts engage in market definition, more or less explicitly, in a wide range of trademark contexts. The most obvious example is in assessing functionality, so it is no surprise we are not the first to observe the significance of market definition there. ${ }^{13}$ But the question of competitive need for access to particular features arises in a variety of contexts in trademark law, and courts necessarily engage in something quite similar to market definition in a number of areas not conventionally thought of in these terms.

\section{Functionality}

Courts have long been divided over the purpose of the functionality doctrine. On one view, functionality serves primarily as a means of preserving access to competitively important features. For these courts, "the effect upon competition "is really the crux of the matter" "14 in functionality cases; the issue is "not the right to slavishly copy articles which are not protected by patent or copyright, but the need to copy those articles, which is more properly termed the right to compete effectively." 15 Functionality, from this perspective, refers to the utility of the design of an object, which "is determined in light of 'superiority of

12. TrafFix Devices, Inc. v. Mktg. Displays, Inc., 532 U.S. 23, 32 (2001) (quoting Qualitex Co. v. Jacobson Prods. Co., 514 U.S. 159, 165 (1995)).

13. See, e.g., Anna F. Kingsbury, Market Definition in Intellectual Property Law: Should Intellectual Property Courts Use an Antitrust Approach to Market Definition?, 8 Marq. Intell. Prop. L. Rev. 63, 66-75 (2004).

14. In re Morton-Norwich Prods., Inc., 671 F.2d 1332, 1341 (C.C.P.A. 1982) (citation omitted).

15. Id. at 1339 (emphases added). 
design,' and rests upon the foundation 'essential to effective competition."'16 Because courts cannot determine what is "essential to effective competition" without understanding the market in which the parties participate, market definition is necessarily implicated in this view of functionality. Competition takes place within markets, and one's "need" to use a particular feature depends on the nature of the market in which it wants to participate.

The Supreme Court appeared to downplay this understanding of functionality in TrafFix Devices, Inc. v. Marketing Displays, Inc. ${ }^{17}$ in which the Court emphasized the functionality doctrine's role in channeling protection of useful product features to the patent system ${ }^{18}$ and therefore put much greater emphasis on expired utility patents as evidence of functionality. ${ }^{19}$ The Court made clear

16. Id. at 1340 (citation omitted); see also Thomas \& Betts Corp. v. Panduit Corp., 138 F.3d 277, 288 (7th Cir. 1998); Sunbeam Prods., Inc. v. West Bend Co., 123 F.3d 246, 255 (5th Cir. 1997) ("The ultimate inquiry concerning functionality ... is whether characterizing a feature or configuration as protected will hinder competition or impinge upon the rights of others to compete effectively in the sale of goods." (citations and internal quotation omitted)); Sno-Wizard Mfg., Inc. v. Eisemann Prods. Co., 791 F.2d 423, 425 n.3 (5th Cir. 1986) (explaining that the Morton-Norwich effects-on-competition inquiry is the appropriate functionality test).

By and large, the Federal Circuit stayed true to Morton-Norwich in the years preceding TrafFix. See, e.g., Midwest Indus., Inc. v. Karavan Trailers, Inc. 175 F.3d 1356, 1361-62 (Fed. Cir. 1999) (en banc) (noting that the Federal Circuit and its predecessor had "repeatedly held that the availability of trade dress protection does not depend on whether a patent has been obtained for the product or feature in question" and defining functionality, the sole mechanism for preventing trade dress from having "anti-competitive effects," in terms of whether a feature "possesse[s] such utility that its protection would hinder competition" (citation and internal quotation marks omitted)); In re Bose Corp., 772 F.2d 866, 872 (Fed. Cir. 1985) ("If the feature asserted to give a product distinctiveness is the best, or at least one, of a few superior designs for its de facto purpose, it follows that competition is hindered. Morton-Norwich does not rest on total elimination of competition in the goods."); New England Butt Co. v. Int'1 Trade Comm'n, 756 F.2d 874, 879 (Fed. Cir. 1985) (relying on the Morton-Norwich factors and stating that "Morton-Norwich emphasizes that functionality is to be determined in light of the competitive necessity to copy"); In re R.M. Smith, Inc., 734 F.2d 1482, 1484 (Fed. Cir. 1984) ("[T]he reason the de jure functional rejection exists is, as stated in Morton-Norwich, because '[T]he public policy involved in this area of the law [is], not the right to slavishly copy articles which are not protected by patent or copyright, but the need to copy those articles, which is more properly termed the right to compete effectively.", (second and third alteration in original) (quoting Morton-Norwich, 671 F.2d at 1339)).

But the Federal Circuit did occasionally nod in the direction of a channeling function. See Textron, Inc. v. U.S. Int'l Trade Comm'n, 753 F.2d 1019, 1024 (Fed. Cir. 1985) ("The reason for the functionality limitation, as explained in the seminal Morton-Norwich case, is to protect the fundamental right to compete through imitation of a competitor's superior product, which right can only be temporarily denied by the patent or copyright laws.").

17. 532 U.S. 23 (2001).

18. See Vornado Air Circulation Sys., Inc. v. Duracraft Corp., 58 F.3d 1498, 1506-10 (10th Cir. 1995).

19. TrafFix, 532 U.S. at 29 (holding that an expired utility patent "has vital significance in resolving the trade dress claim" because a "utility patent is strong evidence that the features therein claimed are functional"); $i d$. at 29-30 (noting that, where the claimed features are unregistered trade dress, this "strong evidence" of functionality "adds great weight to the statutory presumption that features are deemed functional until proved otherwise"). For courts that view functionality as focused on competitive need, expired utility patents are relevant to the question of functionality, but they are only one factor. See Morton-Norwich, 671 F.2d at 1340-41 (noting that the existence of an expired utility patent which discloses the utilitarian advantage of the design claimed as a trademark is evidence that the 
that a design is functional if it "affects the cost or quality of an article," 20 whether or not competitors need to copy that feature to compete effectively. As a conceptual matter, such a shift in emphasis away from competitive need is important because not all formerly patented features are, in fact, competitively necessary. ${ }^{21}$ Practically speaking, deemphasizing competitive need would reduce pressure on the courts to define markets because the functionality determination could be made without reference to the effect on the market. ${ }^{22}$ In fact, however, TrafFix has not rendered competitive need irrelevant.

First, some courts have resisted the Supreme Court's view that functionality is primarily a channeling doctrine and have continued to insist that competitive need is the "crux" of functionality. In Valu Engineering, Inc. v. Rexnord Corp., for example, the Federal Circuit reiterated its view that functionality is concerned with the effect on competition and claimed that the Supreme Court's decision in TrafFix did not change the law of functionality or alter the MortonNorwich analysis. ${ }^{23}$ In particular, the Federal Circuit seized on ambiguity in the Court's definition of a functional feature as one that is "essential to the use or purpose of the article" or that "affects [the article's] cost or quality," 24 insisting that the availability of alternative designs remains relevant to the question of whether a feature is "essential to the use or purpose of the article." 25 For the Federal Circuit, essentiality is relative: features are essential when there are no

design is functional). Morton-Norwich identified three other relevant factors: (1) whether the originator touts the design's utilitarian advantages through advertising; (2) whether alternative designs are available; and (3) whether the design results from a comparatively simple or cheap method of manufacturing the article. $I d$. at 1341.

20. See TrafFix, 532 U.S. at 32 (“'In general terms, a product feature is functional,' and cannot serve as a trademark, 'if it is essential to the use or purpose of the article or if it affects the cost or quality of the article." (quoting Inwood Labs., Inc. v. Ives Labs., Inc., 456 U.S. 844, 850 n.10 (1982)).

21. Cf. Am. Safety Table Co. v. Schreiber, 269 F.2d 255, 271-73 (2d Cir. 1959) ("In approaching the question of whether Schreiber \& Goldberg's copying of the Amco machine is actionable, it must be remembered that the interests and equities of the litigants at bar are not the only ones which must be considered. Indeed, the underlying principles of our competitive economy and the desirability of passing on to the American public the advances of technical progress not only are entitled to consideration, in fact they dominate the picture . . . [I]mitation is the life blood of competition. It is the unimpeded availability of substantially equivalent units that permits the normal operation of supply and demand to yield the fair price society must pay for a given commodity.").

22. Robert G. Bone, Enforcement Costs and Trademark Puzzles, 90 VA. L. Rev. 2099, 2174-81 (2004) (arguing that courts make intuitive judgments about markets in functionality cases and often define them too broadly); $c f$. Thomas F. Cotter, The Procompetitive Interest in Intellectual Property Law, 48 WM. \& MARY L. Rev. 483, 538 (2006) (arguing that the cost of defining markets in functionality cases is too great and we might be better served by simply eliminating protection for product configurations altogether).

23. 278 F.3d 1268, 1276 (Fed. Cir. 2002) ("We do not understand the Supreme Court's decision in TrafFix to have altered the Morton-Norwich analysis."); id. ("We find it significant that neither party argues that TrafFix changed the law of functionality ....").

24. Id. at 1275-76 (quoting TrafFix, 532 U.S. at 33).

25. Id. at 1276 (emphasis added) ("[W]e do not read the Court's observations in TrafFix as rendering the availability of alternative designs irrelevant."). 
good alternatives available to competitors. ${ }^{26}$ This view is mistaken, in our view, because it ignores the fact that the Supreme Court said that features are also functional when they "affect [the article's] cost or quality," and because the Court in TrafFix evaluated whether the dual-spring design was "essential" without considering alternative designs. But if courts are to focus on essentiality and define that concept by reference to alternatives, then market definition will frequently be outcome-determinative: whether there are good alternatives depends entirely on how one describes the market in which one is trying to compete.

Competitive need remains an important part of functionality for a second reason: in TrafFix the Supreme Court explicitly distinguished aesthetic and mechanical functionality, emphasizing the channeling function with respect to the former but not the latter. Where the issue is mechanical functionality, courts need not consider whether a feature is competitively necessary once it has been determined that the feature "is essential to the use or purpose of the device or when it affects the cost or quality of the device." ${ }^{27}$ In cases of aesthetic functionality, by contrast, "[i]t is proper to inquire into a significant nonreputation-related disadvantage." ${ }^{28}$ Whether there is any distinction to be drawn between a "significant non-reputation-related disadvantage" and a "competitive need," under either standard courts must focus more closely on the relationship between the plaintiff and defendant in some market. Market definition, then, remains critical in aesthetic functionality cases. ${ }^{29}$

Sometimes courts explicitly talk about the market as part of the functionality analysis, though almost never by reference to any methodology. Take, for example, Dippin' Dots, Inc. v. Frosty Bites Distribution, Inc. ${ }^{30}$ In that case, the plaintiff argued that the color, shape, and size of its flash-frozen ice cream beads were nonfunctional because Frosty Bites "could still compete in the ice cream market by producing, e.g., soft-serve ice cream, which would not have many of the same functional elements as dippin'dots and thus would not infringe upon DDI's product trade dress." 31 The court found that argument "unavailing" because Frosty Bites "d[id] not want to compete in the ice cream business; it

26. This view is hard to square with the Supreme Court's actual decision in TrafFix, which found the dual-spring design at issue functional despite evidence that alternative designs were readily available at little additional cost. See Traffix, 532 U.S. at 27-28, 33-34.

27. Id. at 33 .

28. Id. (internal quotation marks omitted).

29. See Jay Franco \& Sons, Inc. v. Franek, 615 F.3d 855, 860-61 (7th Cir. 2010) (finding a round beach towel functional and acknowledging that, when assessing competitive need for a claimed feature "[t]he composition of the relevant market matters"). Having acknowledged this, however, the court declined to define a relevant market, instead simply noting that "the more rudimentary and general the element-all six-sided shapes rather than an irregular, perforated hexagon; all labels made from tin rather than a specific tin label; all shades of the color purple rather than a single shade - the more likely it is that restricting its use will significantly impair competition." Id. at 860.

30. 369 F.3d 1197 (11th Cir. 2004).

31. Id. at $1203 \mathrm{nn} .7,9$. Specifically, the plaintiff argued that those features were not aesthetically functional. Id. at 1203-05. As we discuss infra, courts universally have accepted that competitive need 
want[ed] to compete in the flash-frozen ice cream business, which is in a different market from more traditional forms of ice cream.. ${ }^{32}$ Perhaps the court was right in its conclusion - in fact, we share the court's intuition here-but the point is just that the conclusion was not based on any apparent methodology. Indeed, the court made no attempt even to explain its conclusion that flashfrozen ice cream was in a different market than traditional ice cream.

The court in Topps Co., Inc. v. Gerrit J. Verburg Co. ${ }^{33}$ similarly rested its decision on a determination of the relevant market. In that case, the defendant claimed that the design of Topps's Ring Pop ${ }^{34}$ was aesthetically functional because a diamond-shaped candy element was necessary to compete with Topps and there was no way to configure a diamond-shaped candy element without coming close to the Topps design. As the court recognized, the defendant's "functionality argument rest[ed] on the contention that the product category at issue [was] "diamond engagement shaped lollipops." ${ }^{35}$ The court, however, rejected this definition of the market, insisting that courts "define product lines rather broadly for purposes of determining functionality" and that "[a]n infringer cannot circumvent trade dress protection by asserting a defense of functionality on the theory that the prior user's design constitutes a narrow product line, with which the infringer can only compete by copying the prior user's design elements." ${ }^{36}$ Hence, the court concluded, "[d]iamond engagement shaped lollipops do not constitute a distinct product line within the candy industry." ${ }^{37}$ The relevant product line, according to the court, was lollipops, and plenty of alternative lollipop designs were available, including one design actually used by the defendant: a lipstick container with a cylindrically shaped candy element. ${ }^{38}$

is the only relevant consideration in aesthetic functionality cases, so the concern about market definition is particularly pronounced.

32. Id. at 1203 ("[F] unctionality ... is not to be determined within the broad compass of different but interchangeable products; the doctrine of functionality is intended to preserve competition within the narrow bounds of each individual product market." (quoting 3 Louis Altman \& Malla Pollack, Callmann on Unfair Competition, Trademarks and Monopolies $\S 19: 7$, at 19-79 (rev. 4th ed. supp. 2003))).

33. No. 96-cv-7302, 1996 WL 719381 (S.D.N.Y. Dec. 13, 1996).

34. The Ring Pops were described as "comprised of a candy portion in the shape of a solitaire jewel [with 8 facets], supported by a plastic base portion in the form of a stylized, or 'play,' ring. The Ring Pop is held by inserting a finger through the ring, and the candy is then licked." $I d$. at*1.

35. Id. at *7.

36. Id. at $* 8$.

37. Id.

38. In fact, the court believed there were plenty of available alternatives even if the defendant needed to make a jewel or diamond-shaped candy element. Id. at *9 ("Verburg's assertion that it could not come up with alternative designs is unpersuasive. As a matter of common sense and everyday experience, as well as testimony offered by Topps, there are limitless possible configurations for a jewel or diamond-shaped candy element, notwithstanding Verburg's statement that he had never seen an actual diamond fashioned or cut in a configuration other than that employed for these candy products."). But if the court was right that there were plenty of alternative designs of diamond-shaped candy elements available (and if the court could be taken to mean not just that other shapes were physically 
The Topps court was hardly alone in drawing the relevant market broadly. In Brandir International, Inc. v. Cascade Pacific Lumber Co. ${ }^{39}$ the Second Circuit reversed the district court's conclusion on summary judgment that the RIBBON bicycle rack was functional because the district court had not focused sufficiently on whether the product's particular shape and design was dictated by its function as a bike rack, rather than simply performing that function. ${ }^{40}$ The court emphasized that " $[\mathrm{t}] \mathrm{his}$ issue of functionality on remand should be viewed in terms of bicycle racks generally and not one-piece undulating bicycle racks specifically." ${ }^{41}$ Similarly, in Warner Bros. v. Gay Toys, Inc. ${ }^{42}$ and In re DC Comics, Inc. ${ }^{43}$ the courts refused to define the relevant markets in terms of the characters or plot elements of particular comics or shows: the Warner Bros. court found that the relevant market was toy cars generally, not "Dukes of Hazzard" toy cars, ${ }^{44}$ and the relevant market in DC Comics was one comprised of toy dolls generally and not Superman, Batman, or Joker dolls. ${ }^{45}$

Our point here isn't to argue the correctness of the courts' functionality findings in any of these particular cases. It is simply to point out that, to the extent these decisions are based on conclusions about competitive need for a feature, courts must engage in market definition. The more broadly a court defines the relevant market, the less any particular design appears necessary; the more narrowly it describes the market, the more granting exclusive rights to particular design features seems to impose competitive harm. And courts appear to define markets in these cases entirely by their own intuition. Why is the relevant market in Brandir the market for bike racks generally and not ribbonshaped bike racks, while the market in Dippin' Dots is for flash-frozen icecream dots, not ice cream generally? Why, in Warner Bros., don't "Dukes of Hazzard" toy cars constitute a discrete market? The opinions in these cases reveal no methodology, though it is hard to resist the sense that the courts' conclusions were less about whether exclusive use of the features at issue would impose a competitive disadvantage in a relevant market than about whether the

possible, but that they were adequate substitutes in the market), then it did not need to define the market so broadly as lollipops in general.

39. 834 F.2d 1142 (2d Cir. 1987).

40. Id. at 1148 ("There are numerous alternative bicycle rack constructions. The nature, price, and utility of these constructions are material issues of fact not suitable for determination by summary judgment. For example, while it is true that the materials used by Brandir are standard-sized pipes, we have no way of knowing whether the particular size and weight of the pipes used is the best, the most economical, or the only available size and weight pipe in the marketplace. We would rather think the opposite might be the case. So, too, with the dimension of the bends being dictated by a standard formula corresponding to the pipe size; it could be that there are many standard radii and that the particular radius of Brandir's RIBBON Rack actually required new tooling." (footnote omitted)).

41. Id.; see also Weber-Stephen Prods. Co., 3 U.S.P.Q.2d (BNA) 1659, 1667 (T.T.A.B. 1987) (defining the relevant market as barbeque grills generally).

42. 724 F.2d 327 (2d Cir. 1983).

43. 689 F.2d 1042 (C.C.P.A. 1982).

44. 724 F.2d at 330.

45. 689 F.2d at $1044-45$. 
courts believed the plaintiffs in those cases were entitled to impose those costs. $^{46}$

Matters are not helped by statements like the one in Topps that "[a]n infringer cannot circumvent trade dress protection by asserting a defense of functionality on the theory that the prior user's design constitutes a narrow product line, with which the infringer can only compete by copying the prior user's design elements. ${ }^{47}$ In fact, the existence of an aesthetic functionality doctrine attests to the fact that defendants can sometimes circumvent trade dress protection by asserting that the prior user's design constitutes a narrow product line. That is precisely what the defendant did in Dippin'Dots. The real question is when the features claimed by the plaintiff as trade dress define a relevant market. And courts haven't offered any satisfactory answer to that question.

\section{Genericness}

Trademark law's most basic principle is that protection depends on source indication. To be a trademark, a claimed term must indicate the source of the goods or services with which it is used. Terms that instead simply name a category of product or service are deemed "generic," and they can never be trademarks. ${ }^{48}$ The primary significance of the term to the relevant consuming public controls, ${ }^{49}$ but courts have articulated the test of genericness in several similar ways.

Some courts, including the Supreme Court, have used the genus/species test, under which generic terms "refe[r] to the genus of which the particular product is a species." 50 Others use the who-are-you/what-are-you test, under which a valid trademark answers the "who" question and a generic term answers the "what" question. ${ }^{51}$ This test is related to, if articulated slightly differently than, a test that finds a term to be generic when its "primary significance . . . is to describe the type of product rather than the producer." 52

46. See generally Mark A. Lemley \& Mark P. McKenna, Owning Mark(et)s, 109 Mich. L. Rev. 137, 146-56 (2010) (describing courts' attraction to free riding arguments and their willingness to stretch doctrine to accommodate that instinct); Mark P. McKenna, (Dys)functionality, 48 Hous. L. Rev. 823, 854-58 (2012).

47. Topps Co. v. Gerrit J. Verburg Co., No. 96-cv-7302, 1996 WL 719381 at *8 (S.D.N.Y. Dec. 13, 1996).

48. 2 J. Thomas McCarthy, McCarthy on Trademarks and Unfair Competition $\$ 12: 1$, at 12-5 (4th ed. 2011) ("Of course, to properly be called an unprotectable 'generic name' in trademark law, the designation must be the name of the same product or service which it is alleged to identify the source of.").

49. See 15 U.S.C. $\$ 1064$ par. 3 (2006) ("The primary significance of the registered mark to the relevant public rather than purchaser motivation shall be the test for determining whether the registered mark has become the generic name of goods or services on or in connection with which it has been used.").

50. Two Pesos, Inc. v. Taco Cabana, Inc., 505 U.S. 763, 768 (1992) (alteration in original) (quoting Abercrombie \& Fitch Co. v. Hunting World, Inc., 537 F.2d 4, 9 (2d Cir. 1976)); see also Park 'N Fly, Inc. v. Dollar Park \& Fly, Inc., 469 U.S. 189, 194 (1985).

51. See, e.g., Rudolph Int'l, Inc. v. Realys, Inc., 482 F.3d 1195, 1198 (9th Cir. 2007).

52. Filipino Yellow Pages, Inc. v. Asian Journal Publ'ns, Inc., 198 F.3d 1143, 1147 (9th Cir. 1999) (quoting Anti-Monopoly, Inc. v. Gen. Mills Fun Grp., 611 F.2d 296, 304 (9th Cir. 1979)). 
The exclusion of generic terms from protection can be explained in two different ways, and both policy justifications are frequently noted by courts. One explanation focuses on the benefits side of the equation, and specifically the lack of benefit to consumers from protection of a generic term. Generic terms do not do the job of a trademark because they do not indicate source, and they therefore do not reduce consumers' search costs or indicate to consumers anything about quality. ${ }^{53}$ But another explanation offered with similar frequency focuses on the costs of protecting a generic term. Here courts often analogize protection of a generic term to conferring a monopoly on the claimant. ${ }^{54}$ In this sense, a generic term names a relevant product category, and giving a particular producer exclusive rights to that term would give that producer a significant advantage over competitors who would be unable to signal to consumers that their products competed in that same market. This latter explanation seems more consistent with the phenomenon of "genericide," in which once-valuable trademarks that clearly did (and still do) connote source to some consumers are nonetheless denied future protection because a substantial majority of the consuming public has come to associate the term not only with the producer but with the entire class of goods. ${ }^{55}$

Whatever the explanation, one might think that, because the genericness rule focuses on the extent to which a term names a relevant category or a type of product, courts would have some methodology for determining the right level of generality at which to identify the products at issue. In a case, for example, involving Chocolate Fudge Soda, is the relevant category fudge-flavored sodas? ${ }^{56}$ Sodas? Beverages? ${ }^{57}$ Courts have occasionally struggled to determine the proper methodology for determining the relevant product class, but no

53. See Am. Cyanamid Corp. v. Connaght Labs., Inc., 800 F.2d 306, 308 (2d Cir. 1986) (“Trademark protection benefits consumers by enabling them to select products on the basis of their origin. This encourages sellers to create and maintain good will by marketing products of reliable quality that consumers associate with their mark. Consumers will not benefit, however, if trademark law prevents competitors from using generic or descriptive terms to inform the public of the nature of their product.").

54. See, e.g., A.J. Canfield Co. v. Honickman, 808 F.2d 291, 305 (3d Cir. 1986) ("The genericness doctrine prevents trademarks from serving as the substitutes for patents, and protects the public right to copy any non-patented, functional characteristic of a competitor's product."); Abercrombie \& Fitch, 537 F.2d at 10 (to protect a generic name would be to "confer a monopoly" on one seller in the sale of the named product); see also Deven R. Desai \& Sandra L. Rierson, Confronting the Genericism Conundrum, 28 CARdozo L. Rev. 1789, 1819 (2007) ("Modern courts refuse to extend trademark protection to generic words or terms because they are concerned that doing so would negatively impact competition.").

55. See, e.g., King-Seeley Thermos Co. v. Aladdin Indus., Inc., 321 F.2d 577 (2d Cir. 1963) (finding "thermos" to be a generic term for vacuum-insulated containers); DuPont Cellophane Co. v. Waxed Prods. Co., 85 F.2d 75 (2d Cir. 1936) (finding "cellophane" to be a generic term for transparent cellulose film); Bayer Co. v. United Drug Co., 272 F. 505 (S.D.N.Y. 1921) (finding "aspirin” to be a generic term for acetyl salicylic acid).

56. See Canfield, 808 F.2d at 308 (finding "chocolate fudge" generic for chocolate-fudge-flavored diet soda).

57. The Canfield court recognized precisely this difficulty, writing that: 
consensus approach appears to have emerged. One court determined the relevant genus on the basis of assumptions about cross-elasticity of demand, ${ }^{58}$ a feature of antitrust doctrine, but courts do not seem to have gravitated generally to antitrust methodology. Indeed, at least one court has explicitly rejected the antitrust approach. ${ }^{59}$

More common is the approach in Genessee Brewing Co. v. Stroh Brewing Co., which seemed to conclude that a product characteristic can itself define a product class: "If a producer introduces a product that differs from an established product class in a particular characteristic, and uses a common descriptive term of that characteristic as the name of the product, then the product should be considered its own genus." ${ }^{.60}$ On this basis the Second Circuit held that "Honey Brown Ale" was a generic term that described a class of goods: honey-brown ales. But in doing so it had to draw some pretty fine lines in beer markets. ${ }^{61}$

\begin{abstract}
We cannot, however, determine the relevant genus on the basis of abstract analysis, intuition or common sense alone. Rather, we first examine the principles and tests that Congress and the courts have developed for judging genericness to determine if any established method is available for distinguishing product brand from product class. We conclude, however, that neither of the two dominant principles of genericness, the primary significance test and its related test of consumer understanding, directly provide an answer to our question, for both tests become applicable only after we have determined the relevant genus. We therefore must develop our own rule out of basic principles of trademark law that is consistent with these tests.
\end{abstract}

Id. at 299.

58. See Trak Inc. v. Benner Ski KG, 475 F. Supp. 1076, 1079 (D. Mass. 1979) ("We even have difficulty determining the genus for which defendants claim 'fishscale' is a generic label. Assuming the genus includes all products for which there is a cross-elasticity of demand, i. e., all types of waxless cross-country skis, there is no evidence that 'fishscale' has ever been used as a label for that genus, and it appears unlikely that it would ever come to designate mohair skis as well as plastic base skis." (citation omitted)). Cross-elasticity of demand refers to the extent to which an increase in the price of one good will cause consumers to switch to a second good instead. See infra notes 107-08 and accompanying text. How the Trak court knew that there was only cross-elasticity of demand among all types of waxless cross-country skis is a mystery.

59. The Canfield court explained its doubts about relying on cross-elasticities of demand while noting the power of brands to create their own markets:

In some situations, this [cross-elasticities] test may be unfair to a manufacturer with strong brand loyalty. Consumers of a particular brand may consider it so superior to others that they are unwilling to shift to other brands despite a significant change in price. Under the cross-elasticity test, that brand would become its own product class, and other manufacturers could use its name. In other circumstances, we imagine that goods with clearly recognized independent product names might prove to be highly cross-elastic; we suspect, for example, that the demand for all sodas varies considerably with the price of others. Again, crosselasticity would not supply a proper test. Accordingly, we are unwilling to endorse a cross-elasticity analysis unless and until we are shown a method of applying it suited to the subtleties of the trademark context.

808 F.2d at 303 n. 18.

60. Genessee Brewing Co. v. Stroh Brewing Co., 124 F.3d 137, 145 (2d Cir. 1997) (quoting Canfield, 808 F.2d at 305-06).

61. For example, the court wrote that: 
The need to identify the relevant consumers is not limited to genericness. To determine whether a descriptive term has acquired secondary meaning, and therefore merits trademark protection, a court must likewise determine whether "the primary significance of the term in the minds of the consuming public is not the product but the producer." 62 Likewise, when courts assess the strength of a mark they must determine which third-party uses of the same or a similar mark count as evidence (where third-party uses tend to cut against a finding of strength). ${ }^{63}$ The only uses that count here are those from the "relevant market," and courts parse product markets creatively in many cases. ${ }^{64}$ Something quite similar could be said about descriptive fair use: to the extent the fairness of a use is driven by an assessment of competitive need to use a term, ${ }^{65}$ there is implicitly in this determination a conclusion about the market in which the defendant is trying to compete. In these cases as well, trademark law is necessarily defining markets, generally without a clear metric for doing so.

\section{B. PATENT}

Market definition plays a role in several patent contexts too because courts are sometimes called on to determine the extent to which there are alternatives

[W]hen applied to an ale, the mark is generic. There are numerous styles of beer in the marketplace, the names of which consist of a time-honored beer category modified by a new, creative ingredient or flavor. Examples include maple porter, pumpkin ale, nut brown ale, raspberry wheat, cranberry lambic, and oatmeal stout. In some of these new beer styles, the innovative ingredient is honey. As a result, there are honey wheats, honey porters, and honey cream ales on the market. Under the Canfield reasoning, which we have adopted, none of these names may be trademarked. Someone is always the first to sell these products, and if that brewer were granted a monopoly on the name, subsequent producers would lose the right to "describe [their] goods as what they are."

Id. at 148 (alteration in original) (quoting CES Publ'g Corp. v. St. Regis Publ'ns, 531 F.2d 11, 13 (2d Cir. 1975)).

62. Kellogg Co. v. Nat'l Biscuit Co., 305 U.S. 111, 118 (1938); see also Inwood Labs., Inc. v. Ives Labs., Inc., 456 U.S. 844, 851 n.11 (1982) ("[S]econdary meaning [is acquired when] . . in the minds of the public, the primary significance of a product feature . . is to identify the source of the product rather than the product itself."). Consumers, however, need not be able to name the source of a product or service; it is sufficient that consumers expect all goods with the same mark to emanate from a single, if anonymous, source. See 15 U.S.C. $\$ 1127$ (2006) (defining a mark as an indicator that "identif[ies] and distinguish[es] [a party's] goods ... from those manufactured or sold by others" and "indicate[s] the source of the goods even if that source is unknown"); MCCARTHY, supra note 48, § 3:9.

63. See, e.g., Maker's Mark Distillery, Inc. v. Diageo N. Amer., Inc., No. 10-5508, 2012 WL 1605755 (6th Cir. May 9, 2012) ("We recognize that "extensive third-party uses of a trademark [may] substantially weaken the strength of a mark."” (alteration in original) (quoting Homeowners Group, Inc. v. Home Mktg. Specialists, Inc., 931 F.2d 1100, 1108 (6th Cir. 1991))).

64. See id. (upholding the district court's conclusion that third-party use of similar dripping wax seals on distilled spirits was unconvincing because it concerned seals used on all distilled spirits and the relevant market was more limited (including tequila and bourbon, but not other distilled spirits)).

65. See Zatarains v. Oak Grove Smokehouse, 698 F.2d 786, 793 (5th Cir. 1983) (focusing on competitors' need to use a claimed term as one factor to consider in determining whether the term is descriptive or suggestive). 
to the patented invention or the range of relevant prior art. ${ }^{66}$

\section{Damages}

The most obvious place we see market definition at work in patent law is in the context of lost profit damages. ${ }^{67}$ Patent law awards damages "adequate to compensate for the infringement." 68 The traditional measure of those damages is the patentee's lost profits: the amount of money the patentee would have made selling the invention had the defendant not infringed. ${ }^{69}$ To determine that, we need to know which other competitors in the market might take the sale away from the patentee, what noninfringing alternatives might serve as substitutes for the patented good, how the presence of infringement affected the price the patentee could charge, and how an increase in price absent that infringement would have affected total demand. ${ }^{70}$ In some circumstances, we may also need to know how the patented product interacts with other, unpatented complements ${ }^{71}$ and even how it interacts with unpatented non-complementary products sold by the patentee. ${ }^{72}$ The analysis of whether a patentee lost profits because of an infringement is, accordingly, quite sophisticated and requires the estimation of supply and demand curves and cross-elasticities of demand. As we note in Part II, these are the classic hallmarks of antitrust market definition and power analysis.

An important category of patentees who are not entitled to lost profits are patentees who don't sell their own products in the market for the patented goods-market definition again. ${ }^{73}$ These patentees, like those who cannot prove lost profits, can fall back instead on a reasonable royalty for the licensing of their patent. Until recently, the reasonable-royalty analysis was comparatively

66. The patent misuse doctrine treats markets more expressly. See 35 U.S.C. § 271(d)(5) (2006) (defining patent misuse to include illegal tying of unrelated goods to a patent license when the patentee "has market power in the relevant market for the patent or patented product on which the license or sale is conditioned"). Because it is largely (though not completely) consonant with antitrust law, see 1 Herbert Hovenkamp et Al., IP And Antitrust § 3.2 (2d ed. 2010 \& Supp. 2011), we consider the treatment of markets in patent misuse cases along with our discussion of antitrust.

67. For discussion of the role of market definition in patent damages, see Marion B. Stewart, Calculating Economic Damages in Intellectual Property Disputes: The Role of Market Definition, $77 \mathrm{~J}$. Pat. \& Trademark OfF. Soc'y 321, 324-30 (1995).

68. 35 U.S.C. $§ 284$ (2006).

69. For detailed discussion, see Mark A. Lemley, Distinguishing Lost Profits from Reasonable Royalties, 51 WM. \& MARY L. Rev. 655 (2009).

70. Id.

71. See, e.g., King Instruments Corp. v. Perego, 65 F.3d 941, 950-51 (Fed. Cir. 1995) (awarding lost profits on the sale of unpatented components sold along with the patented invention).

72. See, e.g., Rite-Hite Corp. v. Kelley Co., 56 F.3d 1538 (Fed. Cir. 1995) (awarding lost profits on the sale of the patentee's unpatented products that competed with the defendant's infringing products).

73. Lemley, supra note 69, at 658. These may include so-called "patent trolls" who don't make any product at all, but merely assert patents against those who do. They may also include companies who sell products in one market but seek revenue from their patents in another market in which they do not sell. 
less sophisticated than the lost-profits analysis. ${ }^{74}$ But developments in the last few years have required more careful attention to the question of what a willing buyer would have agreed to pay to license the patent from a willing licensor. ${ }^{75}$ That question also touches on market definition, albeit less directly than in the lost profits context. Courts and experts distinguish among prior comparable licenses in part by asking which are the most relevant to the current patent, which requires some assessment of competitive proximity. Further, reasonable royalties, like lost profits, require consideration of available noninfringing alternatives, which means that courts must identify other technologies that are sufficiently different from the patent to avoid infringement but still close enough that they serve as functional substitutes for the patented product in the minds of actual consumers of that product. ${ }^{76}$ Notably, in contrast to the sophisticated market definition process associated with lost profits cases, market definition in reasonable royalty cases remains rudimentary and largely implicit, subsumed in the overarching question of what people in "this industry" would have paid for a license. ${ }^{77}$

\section{Nonobviousness}

The nonobviousness determination requires courts to ask whether a person having ordinary skill in the art would have found the claimed invention obvious in light of the relevant prior art. ${ }^{78}$ Making this determination requires a court first to determine what prior art is relevant so that the invention may be compared to the proper baseline. ${ }^{79}$ And not all prior art makes the grade. To determine the relevant prior art, courts ask (in part) something analogous to a market definition question: what references come from the "same field of endeavor" ${ }^{80}$ Answering that question requires us to know how to define the type of invention at issue (or at least its "field of endeavor") so that we can determine its obviousness. This isn't market definition per se; two things might

74. Id. at 656 .

75. See, e.g., Uniloc USA Inc. v. Microsoft Corp., 632 F.3d 1292, 1317-18 (Fed. Cir. 2011); Lucent Techs. v. Gateway, Inc., 580 F.3d 1301, 1324-25 (Fed. Cir. 2009).

76. Grain Processing Corp. v. Am. Maize-Prods. Co., 185 F.3d 1341, 1349 (Fed. Cir. 1999); Lemley, supra note 69 , at 658 n.16.

77. For criticism and suggestions for ways to make the reasonable royalty test more rigorous, see Daralyn J. Durie \& Mark A. Lemley, A Structured Approach to Calculating Reasonable Royalties, 14 LEWIS \& Clark L. Rev. 627 (2010).

78. 35 U.S.C. § 103(a) (2006), amended by Leahy-Smith America Invents Act, Pub. L. No. 112-29, § 3(c), 125 Stat. 284, 287 (2011) (replacing the first-to-invent system with a first-to-file system).

79. See Graham v. John Deere Co., 383 U.S. 1, 17-18 (1966) (“Under $§ 103$, the scope and content of the prior art are to be determined; differences between the prior art and the claims at issue are to be ascertained; and the level of ordinary skill in the pertinent art resolved. Against this background, the obviousness or nonobviousness of the subject matter is determined.").

80. In re Bigio, 381 F.3d 1320, 1325 (Fed. Cir. 2004) ("Two separate tests define the scope of analogous prior art: (1) whether the art is from the same field of endeavor, regardless of the problem addressed and, (2) if the reference is not within the field of the inventor's endeavor, whether the reference still is reasonably pertinent to the particular problem with which the inventor is involved."). 
be in the same "field of endeavor" even though they don't compete in any meaningful sense, and vice versa. ${ }^{81}$ And even prior art from outside the field will sometimes be considered if it is relevant to the particular problem being solved. ${ }^{82}$ But, because it often requires an assessment of an invention's field of endeavor, the obviousness determination will, in some cases, entail a determination that at least resembles market definition.

In the utility patent context, "field of endeavor" generally is defined functionally rather than by reference to market alternatives. ${ }^{83}$ And in this context, unlike patent damages, a functional approach may be appropriate. The market definition problem is much more pointed in the design patent context, however, because the relevant prior art cannot be defined by function there. Design patents, by definition, do not cover function. Thus, although courts define the relevant prior art as the art to which a person of ordinary skill would look for design inspiration, that category is more likely to track a relevant market than is the "field of endeavor" determination in utility patent law. ${ }^{84}$

\section{COPYRIGHT}

Just as in the trademark and patent contexts, courts in copyright cases sometimes delineate the boundaries of copyright rights by considering market conditions. That means that courts sometimes engage in market definition here as well.

\section{Distinguishing Ideas from Expression}

It is black-letter copyright law that protection attaches only to expression and not to the ideas embodied therein. ${ }^{85}$ Courts must therefore distinguish ideas from expression both to determine what the plaintiff in a copyright case actually owns and to determine whether a particular defendant's work infringes. ${ }^{86}$ And as Judge Learned Hand famously observed, this is a difficult task because

81. Cf. In re Clay, 966 F.2d 656, 659-660 (Fed. Cir. 1992) (stating that the prior art reference was not in the same field even though it was owned by the same company because the invention related to petroleum storage and the prior art related to petroleum extraction).

82. In re Paulsen, 30 F.3d 1475, 1482 (Fed. Cir. 1994) (concluding that laptop designers would look to prior art of door hinges when designing hinged laptop screen).

83. See In re Bigio, 381 F.3d at 1325 (rejecting the contention that the "field of endeavor" test is unworkable because of the lack of clear guidelines and stating that the "test for analogous art requires the [examiner] to determine the appropriate field of endeavor by reference to explanations of the invention's subject matter in the patent application, including the embodiments, function, and structure of the claimed invention").

84. See, e.g., Hupp. v. Siroflex of Am., Inc., 122 F.3d 1456, 1462 (Fed. Cir. 1997) ("The scope of the prior art is not the universe of abstract design and artistic creativity, but designs of the same article of manufacture or of articles sufficiently similar that a person of ordinary skill would look to such articles for their designs.").

85. See Feist Publ'ns, Inc. v. Rural Tel. Serv. Co., 499 U.S. 340, 350 (1991).

86. See id.; see also Computer Assocs. Int'l, Inc. v. Altai, Inc., 982 F.2d 693, 714 (2d Cir. 1992) (filtering out unprotectable elements of computer program and comparing remaining protectable elements to defendant's work). 
$[u]$ pon any work ... a great number of patterns of increasing generality will fit equally well, as more and more of the incident is left out. The last may perhaps be no more than the most general statement of what the play is about, and at times might consist only of its title; but there is a point in this series of abstractions where they are no longer protected, since otherwise the playwright could prevent the use of his "ideas," to which, apart from their expression, his property is never extended. ${ }^{87}$

To take a modern example, when Mattel sued the makers of the Bratz line of dolls, claiming the dolls too closely resembled those depicted in preliminary sketches to which Mattel owned rights, the Ninth Circuit held that the district court erred because it failed to filter out the unprotected idea of "fashion dolls with a bratty look or attitude, or dolls sporting trendy clothing." 88 For the Ninth Circuit, without those elements filtered out, Mattel would gain monopoly control over a certain type of doll.

For our purposes, the important question is why the dolls were appropriately described at that level of specificity. Implicit in Judge Kozinski's opinion is the notion that exclusive rights over "fashion dolls with a bratty look or attitude, or dolls sporting trendy clothing" would have given Mattel power over a significant market segment-hence the concern about monopoly. But how does the Ninth Circuit know that exclusive rights to "fashion dolls with a bratty look or attitude" would impose significant competitive costs? The conclusion depends on an implicit judgment about what sorts of things compete in a relevant market. If nonbratty dolls were a good substitute for bratty dolls, there would be no reason to worry about giving Mattel protection over the latter, at least from a competitive standpoint. Put in copyright terms, we might define the idea at a higher level of abstraction, perhaps as "dolls."

In fact, Mattel is fairly representative in this respect: the idea-expression dichotomy relies on an implicit market definition and application of that rule tends to imply fairly narrow markets. In common parlance, we might speak broadly of markets for "books" or "romance novels," but copyright law parses the markets much more narrowly, defining markets as something more akin to the one identified by Judge Learned Hand: stories in which two children of feuding families fall in love, marry in secret, and meet a tragic end, and which are designed to appeal to a certain ethnic or religious group. ${ }^{89}$ Whether copyright diverges from antitrust market division in this respect is an issue to which we turn in Part II.

87. Nichols v. Universal Pictures Corp., 45 F.2d 119, 121 (2d Cir. 1930).

88. Mattel, Inc. v. MGA Entm't, Inc., 616 F.3d 904, 916 (9th Cir. 2010).

89. Nichols, 45 F.2d at 119 (distinguishing between two plays about feuding Jewish and Irish families whose children secretly fall in love, marry, and have children in part because they appeal to separate markets). 


\section{Fair Use and Market Harm}

Fair use under section 107 of the Copyright Act is determined by reference to four factors:

(1) the purpose and character of the use, including whether such use is of a commercial nature or is for nonprofit educational purposes;

(2) the nature of the copyrighted work;

(3) the amount and substantiality of the portion used in relation to the copyrighted work as a whole; and

(4) the effect of the use upon the potential market for or value of the copyrighted work. ${ }^{90}$

While the Supreme Court has insisted that consideration of the factors is highly contextual and that no one factor is dispositive, ${ }^{91}$ empirical work suggests that the fourth factor-the effect on the market for the copyrighted work-is effectively determinative in most cases. ${ }^{92}$ Here, in contrast to the idea-expression dichotomy, courts tend to conceive of the market for a copyrighted work very broadly-so that not only do courts consider "the extent of market harm caused by the particular actions of the alleged infringer, but also whether unrestricted and widespread conduct of the sort engaged in by the defendant ... would result in a substantially adverse impact on the potential market for the original." 93 Moreover, according to the Supreme Court, the "enquiry "must take account not only of harm to the original but also of harm to the market for derivative works." 94

The inclusion of what are clearly separate derivative markets might seem to suggest that market definition doesn't really matter in fair use analysis. In fact, however, how one defines the relevant derivative market in these cases has a significant effect on the outcome. ${ }^{95}$ If one believed, for example, that a particular rap song competed in the market with all other rap songs, and that each rap song was more or less interchangeable with the others, then a defendant's use of a particular song might not seem to cause much market harm at all, except in the circularly-defined market for licensing. ${ }^{96}$ If the defendant were required to

90. 17 U.S.C. $\$ 107$ (2006).

91. Campbell v. Acuff-Rose Music, Inc., 510 U.S. 569, 577-78 (1994); Harper \& Row Publishers, Inc. v. Nation Enters., 471 U.S. 539, 549 (1985) (“[T]he statute notes four nonexclusive factors to be considered.").

92. See Barton Beebe, An Empirical Study of U.S. Copyright Fair Use Opinions, 1978-2005, 156 U. PA. L. Rev. 549, 582-83 (2008).

93. Campbell, 510 U.S. at 590 (alteration in original) (internal quotation marks omitted).

94. Id. (quoting Harper \& Row, 471 U.S. at 568).

95. See generally Sara K. Stadler, Relevant Markets for Copyrighted Works, 34 J. CoRP. L. 1059 (2009) (discussing market definition's relevance to, and impact on, copyright law).

96. Cf. Campbell, 510 U.S. at 592-93 (conceiving the relevant question as the effect of a parody rap version of a classic country rock song on the market for nonparody rap derivatives of the song). On the 
pay to use the plaintiff's particular song, there's no compelling reason to believe it would still choose that song (even assuming that the plaintiff would willingly license); plenty of other equally good alternatives are available, potentially at lower costs. If, however, the particular rap song is not readily substitutable, then, assuming all other factors are equal, uses by third parties are likely to cause greater harm because uncompensated uses are more likely to take the place of uses for which the plaintiff would have been paid. Notably, however, courts' determination of the relevant market tends not to be even this sophisticated; they rarely attempt to parse the market beyond genre, nor do they offer any reasons to think genres correspond to markets. ${ }^{97}$

\section{THE PROBLEM WITH IMPLICIT MARKET DEFINITION}

Lack of clarity about market definition in IP cases is to some extent a consequence of inconsistency in defining the terms of the debate. Courts and scholars alike sometimes talk about relevant markets in purely functional terms so that markets are defined by the functional characteristics of the products at issue. Other times, however, markets are defined by consumer demand, which may or may not track functional considerations.

This framing choice, however, tends not to be random but instead generally tracks normative views about the scope of the rights in question. When making the case for strong rights, advocates emphasize the need for incentives and the important role IP rights play in enabling creators to appropriate economic value. They also cite enormous economic losses attributable to infringement, relying heavily on the assumption that most infringements represent lost sales. ${ }^{98}$ This is reflected in the damages phase of litigation, where the notion that there are plenty of available substitutes for the product covered by the applicable IP right - so that access to the particular feature is not particularly valuable-tends to disappear. Courts in trademark cases are frequently persuaded, for example, that the defendant chose the mark to free-ride on the unique value of the mark. ${ }^{99}$ In copyright cases, plaintiffs claim that no other copyrighted work would have been able to satisfy the consumer's needs, so the court can readily assume that the defendant's use took away from what otherwise would have been a sale by

circularity of licensing markets, see Mark A. Lemley, Should a Licensing Market Require Licensing?, 70 LaW \& Contemp. Probs., Spring 2007, at 185.

97. See Campbell, 510 U.S. at 592-93; Micro Star v. FormGen, Inc., 154 F.3d 1107, 1113 (9th Cir. 1998) (assuming that additional levels of play for a video game compete with, rather than complement, the game itself).

98. We see this even more absurdly in the public statements of content owners and government advocates of stronger anti-piracy provisions, who (among other serious methodological flaws) quantify losses attributable to "piracy" by treating every unauthorized use of their work as a lost sale. See, e.g., Julian Sanchez, 750,000 Lost Jobs? The Dodgy Digits Behind the War on Piracy, ARS TeChnICA (Oct. 7, 2008, 11:30 PM), http://arstechnica.com/tech-policy/news/2008/10/dodgy-digits-behind-the-war-onpiracy.ars (criticizing those assumptions).

99. See Lemley \& McKenna, supra note 46 (describing the growing use of the free-riding argument). 
the plaintiff. ${ }^{100}$ And in patent cases, plaintiffs are happy to draw fine distinctions between available substitutes in order to claim lost profits. ${ }^{101}$ In short, courts setting remedies define markets narrowly in order to emphasize the harm the plaintiff claims to have suffered.

Where the issue is concern about the scope of IP rights and their general effects on competitors or on the ability of others to speak, by contrast, parties and advocates of broad IP rights define markets broadly so as to downplay the consequences of IP rights. So, for example, advocates of broad trademark rights dismiss concerns about the effects of those rights by claiming that trademark protection has few competitive costs since others can simply choose another market at little cost. ${ }^{102}$ In copyright, concerns about the costs of protection are brushed aside on the ground that copyright doesn't create any market power because it allows others to create competing, functionally equivalent works. ${ }^{103}$ And in patent law, we have seen a consensus develop that patents do not confer

100. See, e.g., United States v. Dove, 585 F. Supp. 2d 865, 869 (W.D. Va. 2008).

101. See, e.g., Zygo Corp. v. Wyko Corp., 79 F.3d 1563, 1571 (Fed. Cir. 1996).

102. See William M. Landes \& Richard A. Posner, The Economic Structure of Intellectual Property LAW 172-73 (2003) ("The number of distinctive yet pronounceable combinations of letters to form words that will serve as a suitable trademark is very large, implying a high degree of substitutability and hence only a slight value in exchange. . . At least in the case of a fanciful mark, then, the social costs of legal protection of trademarks are modest, both absolutely and in relation to the benefits discussed earlier. Other kinds of mark [sic] involve higher but still manageable costs, and marks that involve costs in excess of their benefits are denied legal protection.”). But see Stephen L. Carter, The Trouble With Trademark, 99 Yale L. J. 759, 760 (1990) (calling into question "the premise [of the traditional economic justification for trademark law] that the set of available marks is virtually infinite and, in consequence, that the actual mark chosen by a firm to represent its goods is irrelevant").

103. See, e.g., Christopher Yoo, Copyright and Product Differentiation, 79 N.Y.U. L. Rev. 212, 218-19 (2004) [hereinafter Yoo, Copyright and Product Differentiation] (arguing that the ideaexpression dichotomy, which precludes protection for the underlying ideas of a work and therefore leaves others free to create "alternative works with the same functional characteristics as any existing work" effectively "dissipates authors' monopoly power"); id. at 218 n.16 ("There are no barriers preventing another author from putting pen to paper and attempting to create a substitute for any written work. In other words, although copyright prohibits others form copying the specific words penned by J.K. Rowling without her permission, it does nothing to prevent any other person from writing stories about a school where children learn to perform magic. The inputs needed to create substitutes for more complex media are generally freely available."); Christopher S. Yoo, Copyright and Public Good Economics: A Misunderstood Relation, 155 U. PA. L. Rev. 635 (2006); see also Paul Goldstein, Copyright, 55 Law \& Contemp. Probs. 79, 84 (1992) (arguing that, because "one author's expression will always be substitutable for another's," copyright will generally not create monopoly power); Edmund W. Kitch, Elementary and Persistent Errors in the Economic Analysis of Intellectual Property, 53 VAND. L. Rev. 1727, 1730, 1734 (2000) (arguing that "copyrights do not prevent competitors from creating works with the same functional characteristics" and therefore "almost all copyrights ... are not monopolies"); Douglas A. Smith, Collective Administration of Copyright: An Economic Analysis, 8 REs. L. \& ECON. 137, 139 (1986) ("The potential monopoly power for individual holders of copyright whose works must compete with each other is in most instances not likely to be substantial.").

The Supreme Court dismissed speech-related concerns with the similar claim that copyright only limits access to particular words and doesn't prevent one from speaking herself. See Eldred v. Ashcroft, 537 U.S. 186, 221 (2003) ("The First Amendment securely protects the freedom to make-or decline to make-one's own speech; it bears less heavily when speakers assert the right to make other people's speeches."). 
market power-a view that depends on the belief that patented inventions compete with other products in more or less competitive markets. ${ }^{104}$

Perhaps the problem is the lack of clear standards for market definition in IP cases. If we had clear rules for defining markets, parties couldn't take inconsistent positions when it suited them to do so. We would either define markets narrowly, treating IP rights as conferring substantial power and lacking substitutes, or we would treat them as just another property right, unlikely to cause much harm but also unlikely to confer much unique value.

Unlike IP law, antitrust law does exactly that. Antitrust has a long-standing, well-developed methodology for defining markets. Accordingly, in Part II we consider antitrust market definition and whether it offers a way to rationalize the conflicting understandings of market scope and market power in IP cases.

\section{Market Definition and Product Differentiation}

\section{A. MARKET DEFINITION IN ANTITRUST LAW ${ }^{105}$}

Antitrust is about market relationships. It is designed to promote competition. Competition doesn't occur in a vacuum; a company must compete with others in some market. ${ }^{106}$ As a result, the first step in virtually any antitrust case is the definition of the market in which the competitive harm is alleged. ${ }^{107}$ This is true of mergers and monopolization cases, which generally require some quantum of market share as an element of the offense-you can't measure market share without having a market in which to have that share. But it is also true of many agreements. Mergers, joint ventures, and some agreements among competitors are harmless in competitive markets but can impose serious competitive threats in highly concentrated markets. Before those agreements can be characterized as unlawful, the fact finder must establish either the existence of market power or the likelihood that the conduct at issue will create such power or facilitate its exercise. And even in the shrinking set of cases involving conduct antitrust law treats as illegal per $\mathrm{se}^{108}$ — where market power is irrelevant-market definition is still relevant. In order to know whether an agreement is illegal per se, we

104. See Ill. Tool Works Inc. v. Indep. Ink, Inc., 547 U.S. 28, 45-46 (2006) (eliminating the presumption of market power that had been attributed to the tying product in an antitrust case where the tying product was patented). Illinois Tool Works reflected the clear weight of scholarly opinion. See id. at 44 ("[T]he vast majority of academic literature recognizes that a patent does not necessarily confer market power.").

105. Portions of this section are adapted from 1 HovenKAmP ET AL., supra note 66, ch. 4.

106. Alfred Marshall, Principles of Economics 384 (1890) (explaining that the market is "the whole of any region in which buyers and sellers are in such free intercourse with one another that the prices of the same goods tend to equality easily and quickly" (translating Augustin Cournot, REsearches into the Mathematical Principles of the Theory of Wealth ch. 4 (1838))).

107. The principles of market definition for antitrust are elaborated on in 2B PHILliP E. AREEDA \& Herbert Hovenkamp, Antitrust Law: An Analysis of Antirust Principles and Their Application ch. 5 (3d ed. 2006 \& Supp. 2012).

108. For a discussion of the demise of the per se rule, see, for example, Mark A. Lemley \& Christopher R. Leslie, Categorical Analysis in Antitrust Jurisprudence, 93 IowA L. Rev. 1207 (2008). 
need to know whether it is an agreement between competitors, which means we need to determine whether the agreeing parties would have competed absent the agreement.

Antitrust determines market power circumstantially by defining a relevant market and then computing the defendant's share of this market. A relevant market is a collection of goods or services that can profitably be sold at a monopoly price. ${ }^{109}$ For that to be true, the goods in the collection must be effective substitutes for one another, and goods outside the group must not be effective substitutes for goods inside the group. A substitute is effective if it is desirable enough to customers so that a sufficient number of those customers will switch to the substitute if the good's price rises somewhat above cost. If many purchasers will switch, we say that the cross-elasticity of demand between the two goods is high - a change in the price of one good will affect the demand for the other good. Goods with high cross-elasticity of demand are generally thought to compete with each other in the same market. By contrast, if a modest increase in the price of, say, pencils would not cause many people to switch from pencils to pens, the price of pens does not effectively constrain the price of pencils. Cross-elasticity of demand is low, and it doesn't make sense to consider pens and pencils as competing in the same market because the presence of pens isn't constraining the price of pencils. A relevant market, then, is some grouping of sales in which the cross-elasticity of demand between things inside the grouping and things outside the grouping is relatively low. The same is true of geographic as well as product-market space. If customers won't drive more than five miles to get to a grocery store, a grocery store ten miles away is not an effective substitute for a local store; the two are in separate (geographic) markets.

Antitrust market definition also considers supply substitution, which occurs when producers of a somewhat different product are able to shift their production into the price increaser's market. Assume for a moment that cars and minivans could be manufactured using the same technology and distribution systems, and that a maker of cars can quickly and cheaply switch from the production of cars to the production of minivans. In this case, even if customers are unwilling to substitute away from high-priced minivans to cars, producers of cars will constrain minivan pricing by entering the minivan market, making more minivans and fewer cars. Similarly, suppose that a United States' maker of minivans that sells its products locally attempts to increase prices to monopoly levels. If minivans can be shipped inexpensively and producers in Japan or Korea are earning competitive returns in those countries, they will respond to the United States price increase by shipping more minivans into the United

109. See, e.g., H.J. Inc. v. Int'1 Tel. \& Tel. Corp., 867 F.2d 1531, 1537 (8th Cir. 1989) (explaining that a relevant market is "any grouping of sales whose sellers, if unified by a hypothetical cartel or merger, could raise prices significantly above the competitive level" (citation omitted)); see also 2B AREEDA \& HovenKamP, supra note 107, I[ 533b. 
States, with the result that United States minivan prices will fall back to the competitive level. The ease with which suppliers of related goods can move into the market in response to an increase in price determines the "elasticity of supply" or "supply substitutability." 110

Barriers to entry are a third consideration in defining an antitrust market. A barrier to entry is something that deters or delays the entry of new rivals even when the firm or firms in the market are already charging supracompetitive prices. ${ }^{111}$ Entry analysis helps determine the possibility of supply substitution. If entry is so easy that new entrants can flood a market any time incumbents raise prices to supracompetitive levels, the products those incumbents sell cannot be effectively monopolized or cartelized and it doesn't make sense to talk about those products as a separate market. ${ }^{112}$ By contrast, if there is some structural barrier to entry, such as a high fixed cost of initial investment in a plant, a strong patent right or a government licensing process that controls entry, supply substitution from new firms or existing firms making other products is less likely.

A relevant antitrust market is a grouping of sales for which both the crosselasticity of demand and the cross-elasticity of supply with other products are sufficiently low to warrant the conclusion that a significant price increase of that grouping to a supracompetitive level would be profitable and relatively durable. This typically means not merely that the increase will be immediately profitable, but that the monopoly price increase will be profitable for a significant length of time-say, two years. ${ }^{113}$ If the price increase is "transitory"-if the increase causes new entry that drives prices back down-it does not reflect market power.

Finally, the size of an antitrust market necessitates a policy judgment about how large a price increase above the competitive level should be tolerated. ${ }^{114}$ If we regard a price even $1 \%$ above the competitive level as intolerable, we would

110. See 2B AREeda \& HovenKamp, supra note 107, II 561.

111. See Joe S. Bain, Barriers to New Competition: Their Character and Consequences in MAnufacturing Industries (1956). This definition of entry barriers is controversial. Some economists define entry barriers as costs that "must be borne by a firm which seeks to enter an industry but [are] not borne by firms already in the industry." See George J. Stigler, The Organization of Industry 67 (1968); accord C. C. von Weizsacker, A Welfare Analysis of Barriers to Entry, 11 Bell J. Econ. 399, 400 (1980). For an explanation why this is not the best definition for most antitrust purposes, see 2B Areeda \& Hovenkamp, supra note 107, If 420c. See also Richard Schmalensee, Sunk Costs and Antitrust Barriers to Entry, 94 Am. ECON. REv. 471, 472-73 (2004) (arguing that for antitrust purposes Bainian definition of entry barriers is superior to Stiglerian definition).

112. At least that's the theory. For evidence suggesting that the threat of entry may not discipline cartel behavior, see Amanda P. Reeves \& Maurice E. Stucke, Behavioral Antitrust, 86 IND. L.J. 1527 (2011).

113. 1992 Guidelines, supra note $3, \S \S 3.2-3.3$, at 41,561. Notably, the 2010 GuIDELINES, supra note $10, \S 9$, at 28 , still require the price increase to be "non-transitory," but they drop any reference to a period of time.

114. One might think that any amount of market power should be regarded as undesirable; however, (1) in even moderately product-differentiated markets, a small amount of market power is almost always present; and (2) the cost of enforcing antitrust law is high and its outcomes imperfect. An 
respond with a set of rules that defined markets very narrowly because a $1 \%$ price increase might not prompt much supply or demand substitutability. In a wide variety of product-differentiated markets, individual firms can profitably charge more than $1 \%$ above their marginal costs, and under such a rule we would conclude that each such firm is a "monopolist." By contrast, if we regard prices $50 \%$ above cost as tolerable, the methodology produces a significantly broader market definition. Antitrust market definition generally includes in the same market firms that, while not perfect competitors, are able to hold one another's prices to within five or ten percent above the competitive price. ${ }^{115}$ The federal merger guidelines refer to this test as a "small but significant nontransitory increase in price," or SSNIP. If a SSNIP is profitable because the price increase more than compensates the producer for any lost sales, the substitutes are not effective and the product whose price is increased defines a separate market.

\section{B. THE ROLE OF IP RIGHTS IN DEFINING MARKETS}

It is an article of faith in antitrust law that particular companies do not define a relevant market because for most users different brands compete with one another. For example, antitrust might suppose customers are almost indifferent between Chiquita and Del Monte bananas because most believe that there are no significant differences in quality, taste, or other attributes. Antitrust is likely to define a market as "bananas," not "Chiquita bananas." But even when products clearly vary in quality-for example, cars, or laptop computers-the basic assumption in antitrust law is that the products produced by individual companies compete in a larger market of (mostly) like goods. In the rare cases, like Eastman Kodak Co. v. Image Technical Services, Inc. ${ }^{116}$ when antitrust has departed from that assumption, the outcry has been fierce. ${ }^{117}$ To an antitrust lawyer, brands aren't markets; the regulatory agencies may view a collection of premium or mid-tier brands as a relevant market but seldom a single brand. ${ }^{118}$

aggressive market definition rule requiring only a very small price increase would produce a great deal of expensive antitrust litigation with unacceptably high rates of error.

115. The 1992 and 2010 Merger Guidelines use 5\% as the default level but define that price from current levels rather than the competitive level. See 1992 Guidelines, supra note 3, § 1.11, at 41,551-55; 2010 GuIDELINES, supra note $10, \S 4.1 .2$, at 10 . That creates its own set of problems, which we discuss infra notes 149-54 and accompanying text.

116. 504 U.S. 451 (1992). In that case, the Supreme Court held that parts and service for alreadyinstalled Kodak copiers defined separate markets because parts for other copiers were not effective substitutes. The Court assumed that the copiers themselves competed with other brands, but once the customer had purchased a copier, the parts for repairing that copier did not.

117. See, e.g., Benjamin Klein, Market Power in Antitrust: Economic Analysis after Kodak, 3 SuP. Cт. Econ. Rev. 43 (1993); David McGowan, Between Logic and Experience: Error Costs and United States v. Microsoft Corp., 20 Berkeley Tech. L.J. 1185 (2005); David McGowan, Networks and Intention in Antitrust and Intellectual Property, 24 J. CoRp. L. 485 (1999); Carl Shapiro, Aftermarkets and Consumer Welfare: Making Sense of Kodak, 63 Antitrust L.J. 483 (1995).

118. See, e.g., Shapiro, supra note 117. 
However, the situation is more complex than that. Antitrust market definition hearkens back to the days of readily interchangeable commodities, like grain or plywood. Buyers might (or might not) distinguish between different qualities of grain or plywood, but they are unlikely to pay substantially more for grain merely because it comes from Zachy's Farms rather than Acme Plants. Products and brands today, however, often are far more significantly differentiated. ${ }^{119}$ For while trademarks may telegraph information about product quality or seller reputation, ${ }^{120}$ they often do much more. ${ }^{121}$ Neuroscience research shows that brands convey emotional content as well as information about product characteristics, and that people react to their favorite brands in ways that mirror their reaction to religious icons. ${ }^{122}$ This is why, despite the fact that people tend to prefer Pepsi over Coke in blind taste tests, those exposed to the brand names during the test tend to prefer Coke: exposure to the Coca-Cola brand stimulates a region of the brain not stimulated in blind taste tests. ${ }^{123}$ When preferences created by that information or those attachments are substantial and rivals cannot readily attain the same status, then it is simply wrong to say that the brand does not constitute its own relevant market. ${ }^{124}$ Demand is not priceelastic between the two. And the trademark itself prevents supply substitution.

The effects of product differentiation on antitrust market definition are easiest to see. Although we might first think of "cars" as defining a relevant market, in fact there are significant differences between a Mini Cooper, a Suburban, and a Tesla. People in the market for one kind of car may not be satisfied with

119. Among previous discussions, see, for example, Deven R. Desai \& Spencer Waller, Brands, Competition, and the Law, 2010 B.Y.U. L. Rev. 1425; Jared Kagan, Bricks, Mortar, and Google: Defining the Relevant Antitrust Market for Internet-Based Companies, 55 N.Y.L. ScH. L. Rev. 271, 278 (2011); Steven Semeraro, Property's End: Why Competition Policy Should Limit the Right of Publicity, 43 Conn. L. Rev. 753 (2011); Andrew C. Hruska, Note, A Broad Market Approach to Antitrust Product Market Definition in Innovative Industries, 102 YaLE L.J. 305 (1992).

120. See, e.g., LANDES \& PoSner, supra note 102, at 167-68; Stacey L. Dogan \& Mark A. Lemley, Trademarks and Consumer Search Costs on the Internet, 41 Hous. L. REv. 777, 799 (2004); Nicholas S. Economides, The Economics of Trademarks, 78 TRAdEMARK ReP. 523, 525-27 (1988) (discussing the economic benefits of marks that apprise consumers of products' unobservable features); Nicholas S. Economides, Trademarks, in 3 The New Palgrave Dictionary of Economics and the Law 602 (Peter Newman ed., 1998) [hereinafter Economides, Trademarks] (describing the savings for consumers in product searches as one of "[t]he primary reasons for the existence and protection of trademarks"); William M. Landes \& Richard A. Posner, Trademark Law: An Economic Perspective, 30 J.L. \& Econ. 265, 268-70 (1987) (identifying the lowering of brand recognition costs to consumers as the justification for trademark law).

121. See Desai \& Waller, supra note 119.

122. See Martin Lindstrom, Buyology: Truth and Lies About Why We Buy 123-26 (2008). Indeed, Katya Assaf has gone so far as to suggest that brands are religions. Katya Assaf, Brand Fetishism, 43 Conn. L. Rev. 83 (2010); Katya Assaf, Magical Thinking in Trademark Law, 37 Law \& Soc. INQUIRY (forthcoming 2012). We wouldn't go that far, but the studies showing how people react to brands are persuasive.

123. LindSTROM, supra note 122, at 26-27. The results of the underlying study were reported in Samuel M. McClure et al., Neural Correlates of Behavioral Preference for Culturally Familiar Drinks, 44 NEURON 379 (2004).

124. See Desai \& Waller, supra note 119. 
another, and price variations reflect that fact. That doesn't mean that any one of those cars is necessarily in a market by itself, but that antitrust law requires us to investigate customer interests in more detail before defining the relevant market (perhaps it's "high-end sports cars" or "electric cars" or "convertibles").

IP rights contribute significantly to that product differentiation, and hence make it more likely that two products that we think of in the same broad class are not in fact effective substitutes for each other from an antitrust perspective. By definition, IP rights attach to things that are differentiated from their putative competitors. We can copyright our novel precisely because it differs from J.K. Rowling's novel. We can patent our invention only if it is different in a nonobvious way from products invented by others. Further, the existence of IP rights means that the things that differentiate my product from yours cannot be copied. Put another way, an IP right is a barrier to entry that prevents the sort of quick and easy supply substitution that might undermine market power.

This IP-induced product differentiation can sometimes have the effect of excluding other goods in the same functional category from an antitrust-defined market, despite our intuition that the goods must compete. Suppose, for example, that three different pain pills-Bayer Aspirin, Tylenol, and Advil—all sell for 10 cents per pill. Though the three pills perform many similar functions and are considered roughly interchangeable for certain pains, they are also quite different and have different side effects. Acetaminophen, a generic version of Tylenol, then enters the market at a price of 3 cents per pill. In response, the price of branded Tylenol drops to 4 cents, while the prices of branded Bayer Aspirin and Advil show no effect. On these facts, Bayer Aspirin and Advil do not compete with Tylenol in a traditionally-defined antitrust market. ${ }^{125}$ If they did, their higher price would cause so many customers to switch to the nowlower-priced Tylenol that they would have been forced to lower their own prices in response. ${ }^{126}$

In fact, however, the effect of IP rights on market definition is even more dramatic. Tylenol and Advil are brand names for acetaminophen and ibuprofen, respectively. But neither is the subject of a current patent. So anyone is free to copy the chemical formula of those drugs exactly and to produce an acetaminophen or ibuprofen product that competes with Tylenol or Advil. And they do. Curiously, however, those generic alternatives sell at a significant discount compared to the price of brand-name Tylenol or Advil, often as much as $50 \%$

125. In the Ciprofloxacin case, the court concluded that the market was properly limited to Ciproflaxacin because the price of the branded version of that product dropped $95 \%$ when the generic version entered. In re Ciprofloxacin Hydrochloride Antitrust Litig., 363 F. Supp. 2d 514, 521-23 (E.D.N.Y. 2005). This indicated that the preentry price of Ciprofloxacin was significantly above cost and that existing alternative drugs had not been able to discipline that price.

126. For a discussion of the very interesting question of why all three products were priced at 10 cents before entry if they are not in fact competitors, see infra note 148 . 
less. ${ }^{127}$ It is the brand name that makes the difference. Even though generic companies can and do advertise that they have the same ingredients as Tylenol or Advil, and even though they are often placed next to each other on pharmacy shelves, the brand name is sufficient to cause many consumers to pay a higher price for the same basic good. ${ }^{128}$ Interestingly, the same is true even for prescription drugs, for which the decision maker is generally a doctor. ${ }^{129}$

These brand-driven price differences have an interesting antitrust consequence: just as Advil and aspirin might not compete with each other in a relevant antitrust market, Advil and generic ibuprofen might not compete with each other on traditional antitrust analysis. Indeed, a number of courts have held that brand name drugs and their generic equivalents are in separate markets for antitrust purposes. For example, in Geneva Pharmaceuticals Technology Corp. v. Barr Laboratories, Inc., the Second Circuit concluded that a pioneer branded drug and its chemically identical generic substitutes were not in the same relevant product market because so many consumers chose the drug on the basis of its name that a significant price difference persisted between the generic and branded versions. ${ }^{130}$ In that case, the generic had been introduced at a price of $70 \%$ of the price of the branded drug, but subsequently the price of the generic fell to $50 \%$ of the branded drug price. ${ }^{131}$ It might seem odd to say that two

127. See Simon P. Anderson et al., Push-Me Pull-You: Comparative Advertising in the OTC Analgesics Industry 16 tbl.1 (Apr. 27, 2012), http://ssrn.com/abstract=2047106 (comparing pricing "per serving"). On the same dynamic in prescription drugs, see Andrew T. Ching, Consumer Learning And Heterogeneity: Dynamics of Demand for Prescription Drugs After Patent Expiration, 28 InT'L J. InDus. ORG. 619, 621 fig.1 (2010) (showing that, on average, generic prices gradually drop from about $60 \%$ of brand price to $50 \%$ as their market share rises to about $60 \%$ ).

128. Indeed, consumers may even take the lower price as a signal that the generic pills are less effective. See Dan Ariely, Predictably Irrational 83-84 (2008).

129. Judith K. Hellerstein, The Importance of the Physician in the Generic Versus Trade Name Prescription Decision, 29 RAND J. Econ. 108 (1998) (describing the role of physicians in the decision to use brand name drugs or generic substitutes and the tendency of certain physicians to prescribe one or the other, a tendency not explained by patient characteristics). Indeed, prescribing habits may be resistant even to information regarding drugs' serious risks. Sandra H. Johnson, Polluting Medical Judgment? False Assumptions in the Pursuit of False Claims Regarding Off-Label Prescribing, 9 MinN J.L. SCI. \& Tесн. 61, 79 (2008) (“[W]hile changes in drug labeling regarding warnings of previously unknown, serious risks are often mailed or faxed directly to physicians, studies indicate that these mailings do not result in changes in prescribing practice-that physicians frequently prescribed drugs in violation of warnings, including black box warnings." (citing Jerry H. Gurwitz, Serious Adverse Drug Effects-Seeing the Trees Through the Forest, 354 New. EnG. J. Med. 1413, 1414 (2006))).

130. 386 F.3d 485, 497-98 (2d Cir. 2004); cf. Bayer Schera Pharma v. Sandoz, Inc., No. 08-civ03710, 2010 WL 1222012, at *4-*6 (S.D.N.Y. Mar. 29, 2009) (rejecting market definition based on dosage of a pharmaceutical's active ingredient and cautioning against amending complaint to define the market as a single brand); In re Lorazepam \& Clorazepate Antitrust Litig., 467 F. Supp. 2 d 74 (D.D.C. 2006). In Lorazepem, the court concluded that there was sufficient evidence to support the jury's conclusion that the relevant market consisted only of generic manufacturers of a drug. First, many fact witnesses from the industry testified that they did not "consider the brand price in setting their own prices." 467 F. Supp. 2d at 82. Second, "both Plaintiffs' experts and industry participants viewed generics as competing in a different market than the branded manufacturers." Id. Third, the court cited testimony by a plaintiffs' expert that branded and generic drugs have different customer bases and are marketed differently. Id.

131. The court noted that branded 
functionally identical products are in separate markets. But that is because markets aren't always about function; consumers' beliefs about products can drive purchasing behavior even if those beliefs are not based in reality.

The implications aren't limited to pharmaceuticals. IP rights can create their own antitrust market in any product in which consumer loyalty to the brand is strong enough, or in which IP rights make the products different enough. We see brand-based price differentiation among goods of undifferentiated quality in a wide variety of consumer markets. Some brands of gasoline, such as Shell, systematically charge more than their competitors, even when those competitors are across the street. Others, like Arco, charge less. ${ }^{132}$ Consumers willingly pay substantially more for Clorox-brand bleach than for generic bleach, ${ }^{133}$ even

Coumadin's substantially higher prices is evidence of a distinct customer group with brand allegiance and/or high risk sensitivity that was unwilling to switch from the known brand name even in the face of a discounted alternative. That this group has remained loyal despite Coumadin's conspicuously higher prices strongly suggests inelastic demand.

Geneva, 386 F.3d at 496-97.

We also conclude that Coumadin's customers are displaying strongly inelastic demand. Overall generic penetration has not been as significant in the warfarin market as in other drug markets of comparable size: Barr's CEO testified that generic penetration after one year can be as high as 60 percent, but Barr projected only 35 percent penetration after a year and in fact captured just 8 percent of the warfarin market. Three-and-a-half years after generic warfarin was introduced, the generic substitution rate was just over 30 percent despite prices that were 40 percent lower than Coumadin. Such results indicate a substantial customer base that has not responded to lower prices.

Customers that have remained with Coumadin clearly do not perceive generics to be a reasonable substitute for it. Conversely, price-sensitive customers have flocked to the cheaper generic and are likely to view another inexpensive generic as a reasonable substitute. Plaintiffs' evidence suggests that upon generic entry, the consumer base split such that Coumadin and generics each faced smaller, distinct consumer groups.

Id. at 497-98.

For discussion of this issue, see, for example, Anish Vaishnav, Note, Product Market Definition in Pharmaceutical Antitrust Cases: Evaluating Cross-Price Elasticity of Demand, 2011 Colum. Bus. L. REv. 586.

132. See Christi Shafer, Big Gasoline Brands Continue to Lose US Retail Market Share, OIL DaILY, Apr. 20, 2012 (noting that in a recent quarter Arco offered an average discount of 11.1 cents per gallon compared to competitors); see also Jennifer R. Thompson, Brand Loyalty and Gasoline Pricing in Sacramento, 10 Agric. \& Resource Econ. Update 9, 9-11 (2007), available at http://giannini.ucop.edu/ media/are-update/files/articles/v10n6_3.pdf (documenting daily retail gasoline price differences of up to 18.2 cents per gallon between stations and attributing the effect to brand differentiation). This is particularly notable because, as Thompson observes, the brand of gasoline sold at a branded retail outlet may not even have been refined by the brand-name company. Id. Although consumers may believe one brand of gasoline is somehow superior to another, perhaps based on advertising that suggests a particular brand boosts performance, that belief is not rooted in reality. One might quibble whether it is the brand name or the advertising campaign that is causing the artificial product differentiation here, though certainly the brand name is the focus for advertising misinformation.

133. Clorox has a 65\% market share. Datamonitor, Ref. No. 0072-0013, Industry Profile: Bleach IN the United States 2 (Nov. 2011). In 2011, “customers continued to buy products despite" a 12\% increase in pricing for Clorox liquid bleach. Clorox Says Higher Prices Helped Lift Revenue, ReuTERs, Nov. 2, 2011, available at http://www.nytimes.com/2011/11/03/business/clorox-says-higher-prices-helped- 
though the essence of bleach is a simple chemical formula. ${ }^{134}$ Tazo brand organic green mint iced tea and HonestT brand organic green iced tea sell right next to each other in grocery stores for a $30 \%$ difference in price per ounce. ${ }^{135}$ Fans of the Three Tenors might not accept songs by others as a substitute. ${ }^{136}$ And sports fans won't be willing to replace a hat with their team's logo with a hat from a competing sports franchise. ${ }^{137}$ Under traditional antitrust market definition, each of these things are in a separate market. Indeed, some goods (called Veblen or snob goods) invert the traditional price relationship so that demand actually increases rather than decreases with price. Veblen goods, therefore, exhibit a sort of anti-network effect; acquisition of the good by new

lift-revenue.html; $c f$. FTC v. Proctor \& Gamble Co., 386 U.S. 568 (1967) (requiring divestiture of bleach company before approving merger because of concentration in the bleach market).

134. True, like gasoline sellers, bleach companies often include additives in their products, which they point to as differentiating factors. "The basic raw materials for making household bleach are chlorine, caustic soda, and water. However, most modern bleach products contain a variety of ingredients such as surfactants; solvents: agents for adjusting $\mathrm{pH}$ and/or viscosity; colorants; oxidizing agents; corrosion inhibitors and fragrances raw materials." Datamonitor, supra note 133, at 16. But there is little evidence that some bleaches are in fact better than others as a result of these additives. Indeed, this strikes us as a nice example of meaningless differentiation. See, e.g., Jim Wang, Four Ways to Save Money Without Noticing It (Sept. 21, 2010), http:// money.usnews.com/money/blogs/my-money/ 2010/09/21/four-ways-to-save-money-without-noticing ("For products like bleach, it doesn't matter if you buy the generic or Clorox (which is just bleach with a fancy label).").

135. Observation made October 11, 2011, Munger Store, Stanford, California.

136. Polygram Holding, Inc. v. FTC, 416 F.3d 29, 37-38 (D.C. Cir. 2005) (treating Three Tenors albums as existing in their own market).

137. Justice Breyer made this very point about relevant markets in the oral argument for the American Needle case. The issue in that case was whether the NFL should be regarded as a single entity for purposes of licensing merchandise, or whether each of the thirty-two individual teams acted independently in that capacity. During the oral argument, Justice Breyer inquired about the possibility of competition between merchandise of different teams (as opposed to competition between different providers of merchandise of the same team), leading to the following exchange:

JUSTICE BREYER: You want the Red Sox to compete in selling T-shirts with the Yankees; is that right?

MR. NAGER: The ability to compete. Yes.

JUSTICE BREYER: Yes. Okay. I don't know a Red Sox fan who would take a Yankees sweatshirt if you gave it away.

(Laughter.)

JUSTICE BREYER: I mean, I don't know where you're going to get your expert from that is going to say there is competition-

MR. NAGER: Well-

JUSTICE BREYRE [sic]:- between those two products. I think they would rather-they would rather wear a baseball, a football, a hockey shirt.

Transcript of Oral Argument at 17, Am. Needle, Inc. v. Nat'1 Football League, 130 S. Ct. 2201 (2010) (No. 08-661), available at http://www.supremecourt.gov/oral_arguments/argument_transcripts/08661.pdf. For discussion of the market definition problem in sports leagues, see Daniel A. Schwartz, Note, Shutting the Back Door: Using American Needle to Cure the Problem of Improper Market Definition, 110 Мich. L. Rev. 295 (2011). 
consumers actually reduces the value of the good to existing owners. ${ }^{138} \mathrm{~A}$ Veblen good (say, a Rolex watch) may not compete with other watches in a classic sense or even with counterfeit Rolexes because the price the consumer pays for the Rolex is itself part of the value of the product they are buying.

Brands clearly create significant differentiation in the minds of consumers, whether that belief is based on functional differences in the goods being sold. Survey evidence suggests that, across all products, a significant number of consumers would be willing to pay a substantial premium for their brand of choice. According to one study, $72 \%$ of consumers would pay a $20 \%$ premium over the price of the closest competitive brand; $50 \%$ would pay a $25 \%$ premium; $40 \%$ would pay a $30 \%$ premium; and $25 \%$ say "price does not matter" when it comes to purchasing a brand to which they are loyal. ${ }^{139}$ Leaving aside those in the last category, who surely don't mean it, those numbers are not themselves sufficient to justify an across-the-board price increase. The fact that a minority of consumers would switch away from their favorite brand means that a $20 \%$ price increase would not be profitable because the loss of $28 \%$ of the brand's customers would more than outweigh the benefit. But under antitrust law, a $20 \%$ price increase isn't the test; if virtually all customers had enough brand loyalty that they would pay $5 \%$ more, the brand is in a market of its own. ${ }^{140}$ And the self-confessed goal of marketing is precisely to build such insensitivity to price.

Further, these data come from a generalized survey referring to brands without identifying specific products. If the average brand generates such loyalty it shouldn't be too surprising that more famous brands inspire still more loyalty. Cola drinkers are notoriously loyal to their brands, notwithstanding the fact that they seem unable to distinguish among different colas in blind taste tests. ${ }^{141}$ And brand loyalty is even stronger (and price less of a constraint) with luxury goods; the customer who pays $\$ 740$ for a Coach purse may well be

138. See Stan J. Liebowitz \& Stephen Margolis, Seventeen Famous Economists Weigh in on Copyright: The Role of Theory, Empirics, and Network Effects, 18 HARv. J.L. \& Tech. 435, 449-52 (2005) (modeling Veblen goods as a form of negative network effect).

139. Scott M. Davis, Brand Asset Management: Driving Profitable Growth Through Your BRANDS 5 (2002) ("72 percent of customers say they will pay a 20 percent premium for their brand of choice, relative to the closest competitive brand. 50 percent of customers will pay a 25 percent premium. 40 percent of customers will pay up to a 30 percent premium. 25 percent of customers state the price does not matter if they are buying a brand that owns their loyalty.").

140. See supra note 115 and accompanying text.

141. See Sanjoy Dhose \& Oded Lowengart, Taste Tests: Impacts of Consumer Perceptions and Preferences on Brand Positioning Strategies, 10 J. Targeting, Measurement, \& Analysis for MarketING 26, 30 (2001) (showing that, while people tend to prefer Diet Pepsi over Diet Coke in blind taste tests, those who are exposed to the brand names during the test tend to prefer Diet Coke). Remarkably, this is not simply because the respondents want to like Diet Coke better-they actually do like the Diet Coke better when they know it is Diet Coke. Brain scans reveal that the brands stimulate a different region in the brain that is not stimulated in blind taste tests- the region responsible for higher thinking. See Lindstrom, supra note 122, at 26. The results of the underlying study are presented in McClure et al., supra note 123 , at 379 . 
unwilling to change to a less prestigious brand just to save $\$ 37 .{ }^{142}$ Indeed, studies suggest that demand for some luxury goods actually rises with price, so demand would decrease rather than increase at lower prices. Wine drinkers act much the same way, paying ten times as much for one bottle as another despite being unable to taste the difference. ${ }^{143}$ This may be because of brand loyalty or simply because the price of wine actually dominates consumers' experiencesthey value drinking an expensive bottle of wine. ${ }^{144}$ In either case, demand for a product is not determined by its functional characteristics. ${ }^{145}$

Cross-elasticity of demand is a fact-specific question. The evidence doesn't support the conclusion that all brands confer market power, as antitrust law once wrongly assumed. ${ }^{146}$ But it seems quite likely that, for many of the most famous brands and for a variety of goods in which price is a mixed or even affirmatively positive signal of value, trademark owners can easily raise the price of their goods 5-10\% over the cost of an alternative product without their customers deserting them for that product. For those brands, other products of similar type are not in the same market as antitrust defines that term. ${ }^{147}$

This phenomenon is not limited to trademarks. A wide variety of copyrighted works also command significant willingness to pay. If you want to read the final book in the Harry Potter series, you are unlikely to be satisfied by the latest Stephen King novel. And, indeed, people line up in advance to get access to the newest Harry Potter novel, iPhone, or movie, while ignoring a variety of other creative products of the same type available with no wait and frequently at the

142. Indeed, the existence of counterfeit Coach products that sell for far less than the genuine article, see, e.g., Tresa Baldas, Purse Pirates Told to Get a Brand New Bag, Detroit Free Press, Apr. 17, 2011, at A1, suggests that even near-identity of marks may not be sufficient to constrain Coach's price. The question of whether counterfeit goods should "count" in market definition is a thorny one for antitrust law, and we don't explore it further here. For a full discussion, see 1 HovENKAMP ET AL., supra note 66, $\S 4.3 \mathrm{c}$.

143. See, e.g., Robin Goldstein et al., Do More Expensive Wines Taste Better? Evidence from a Large Sample of Blind Tastings, 3 J. WInE Econ. 1 (2008) (finding that nonexpert wine drinkers can't tell the difference between cheap and expensive bottles of wine in blind tastings).

144. Id. at 1 ("[I]ndividuals who are unaware of the price do not derive more enjoyment from more expensive wine."); Hilke Plassmann et al., Marketing Actions Can Modulate Neural Representations of Experienced Pleasantness, 105 Proc. OF THE NAT'L ACAD. OF SCI., 1050, 1050-54 (2008) (finding that subjects appreciated wine more when they believed it sold for $\$ 90$ a bottle than when they tasted the same wine and believed it cost only $\$ 10$ and explaining that "changes in the price of a product can influence neural computations associated with" experienced pleasantness).

145. In one remarkable study, changing the price at which an energy drink was purchased was shown to influence the ability to solve puzzles. See Baba Shiv et al., Placebo Effects of Marketing Actions: Consumers May Get What They Paid For, 42 J. Marketing Res. 383 (2005) (finding that subjects who bought energy drinks at a discounted price completed fewer puzzles on average than subjects who purchased the drink at the regular price); see also Rebecca L. Waber et al., Research Letter, Commercial Features of Placebo and Therapeutic Efficacy, 299 JAMA 1016-17 (2008) (finding that subjects who consume a sugar pill that they believe is a painkiller can tolerate more pain if the pill is described as an expensive drug than when it is presented as an inexpensive drug).

146. See Ill. Tool Works Inc. v. Indep. Ink, Inc., 547 U.S. 28, 45-46 (2006) (overruling prior legal presumption that an IP right conferred market power over a tying product).

147. For detailed discussion, see Desai \& Waller, supra note 119, at 1468-76; Glynn S. Lunney, Jr., Trademark Monopolies, 48 EMORY L.J. 367 (1999). 
same or a similar price. It may be hard to quantify the power over price in a case like that, but it's surely there. ${ }^{148}$ Indeed, Paul Heald finds that books in copyright are more expensive than similarly-situated books whose copyright has expired, suggesting that product differentiation among books provides at least some power over price. ${ }^{149}$

Whether a copyrighted work or group of works constitutes a relevant product market for antitrust purposes depends on the consumer response to price increases, not simply whether there are other works in the same genre. The copyrighted works of a particular musical artist are not a relevant product market so long as enough consumers, in response to a supracompetitive price, would instead purchase the works of other artists that the price increase would be unprofitable. ${ }^{150}$ But if consumers wouldn't switch in response to a modest increase in price, the works are not in the same market. ${ }^{151}$

Patents have a similar effect. Many product patents do little more than create relatively minor enhancements in a product that make it distinctive to one group of customers, and competitors in that product are likely to have their own offsetting patented enhancements. As a result, the markets for automobiles, vacuum cleaners, cleansers, and pharmaceuticals are characterized by numerous patents, most of which suffice to make their products somewhat distinctive in a product differentiated market. For antitrust law, the question is how distinctive those products are. If a small price increase won't dislodge purchasers who want a hybrid gasoline-electric engine in their car, hybrid cars aren't even in the same market as nonhybrid cars with the same brand name.

148. Michael Abramowicz, An Industrial Organization Approach to Copyright Law, 46 WM. \& Mary L. Rev. 33, 45 (2004); Yoo, Copyright and Product Differentiation, supra note 103. Yoo suggests that product differentiation doesn't confer market power because entry by products closer in space can constrain price while giving users choice. Yoo, Copyright and Product Differentiation, supra note 103, at 248-49. But in fact, experience with IP cases suggests that entry often doesn't discipline price. Brand-name drugs remain significantly more expensive than their generic equivalents, and the presence of one luxury brand doesn't bring down the price of a different luxury brand. And the broader IP rights are, the more entry is constrained.

149. Paul J. Heald, Property Rights and the Efficient Exploitation of Copyrighted Works: An Empirical Analysis of Public Domain and Copyrighted Fiction Bestsellers, 92 MinN. L. Rev. 1031, 1034 (2008).

150. See Rock River Commc'ns, Inc. v. Universal Music Grp., Inc., No. 08-cv-635, 2011 WL 1598916, at*15 (C.D. Cal. Apr. 27, 2011) (finding that Bob Marley albums do not constitute a relevant product market unto themselves). But see Polygram Holding, Inc. v. FTC, 416 F.3d 29, 37 (D.C. Cir. 2005) (treating Three Tenors albums as a discrete market).

151. What limited evidence there is suggests that the move from uniform to (frequently higher) variable iTunes pricing reduced the number of sales. Neil Hughes, iTunes Price Increases Mean Slower Sales for Music Labels, ApPLEINSIDER (Feb. 9, 2010, 11:25 AM), http://www.appleinsider.com/articles/10/ 02/09/itunes_price_increases_mean_slower_sales_for_music_labels.html. This suggests that the composite demand curve for music is downward-sloping (which is not surprising; most demand curves are downward-sloping). But if the move was profitable, it also suggests that, at the very least, there are three different categories of songs (the $\$ 0.69, \$ 0.99$, and $\$ 1.29$ buckets) that don't compete on price. See ITUNES, http://www.apple.com/itunes/?cid=OAS-US-DOMAINS-itunes.com (last visited July 2, 2012) (offering songs for download at three different prices). 
Further, the SSNIP test is subject to a well-known problem called the "Cellophane Trap," named after the case that fell into it. ${ }^{152}$ Defining markets by cross-elasticity of demand requires a reference price: If I raise my price by $5 \%$ from some base level, will people switch to a competing good? The problem is that a firm that actually does have monopoly power still faces constraints on its ability to charge whatever price it wants; those constraints are set by consumers' willingness to pay. If a monopolist already charges the profit-maximizing price, an increase above that price will cause enough consumers to stop buying the product to make that price increase unprofitable; that's why the lower price was already profit-maximizing. So we can't just use the price a company already charges as the base level, or we will conclude that even monopolists lack market power. ${ }^{153}$ That's what happened in Cellophane: the Court concluded that cellophane must not be in a market by itself because at some price consumers would stop buying it and use something else instead. In fact, however, cellophane didn't have good substitutes; the patentee had simply raised the price of cellophane as high as it could go without spurring defection. $^{154}$

Antitrust solves this problem by using some measure of average cost, ${ }^{155}$ not the actual market price, as the baseline for the SSNIP test. ${ }^{156}$ But that means that the relevant question is not whether consumers would pay more for a can of Coke or a Harry Potter novel than they currently do; it is whether they would pay $5 \%$ more for the can of Coke than it costs to make, deliver, and sell it. We would need manufacturing cost data to resolve that question conclusively, but it seems extremely likely that most copyrighted works and quite a few trademarked ones sell for more than 5\% over the cost of making them. Thus, the evidence suggests that many goods-even those that appear price-constrained by an alternative-may simply be engaged in price-maximizing behavior up to the constraint of a different product that is not in fact in the same market. ${ }^{157}$

152. United States v. E.I. du Pont de Nemours \& Co., 351 U.S. 377 (1956).

153. George W. Stocking \& Willard F. Muller, The Cellophane Case and the New Competition, 45 Am. Econ. Rev. 29, 54 (1955) (first identifying the problem).

154. See id. at 63.

155. "Cost" is a disputed term in a number of antitrust contexts, particularly predatory pricing. Most economists agree that marginal cost— the cost to make the next unit of a good-is the right measure of cost. But it is essentially impossible to measure in practice. Average variable cost is an imperfect substitute, but it doesn't allocate the fixed costs necessary to develop the product. Average total cost does include those fixed costs, but they will not always be relevant to the purchasing decision. Finally, many economists would include an ordinary return on capital as part of fixed costs, while others would treat it as a profit. For an introduction to these issues, see 3A AREEDA \& HovenKAMP, supra note 107, III 735-41.

156. At least, antitrust does so when it can. In fact, however, the Merger Guidelines indicate that antitrust authorities will often fall back on actual prices, not measures of cost, in calculating the SSNIP. 2010 GUIDELINES, supra note $10, \S 4.1 .2$, at 10 .

157. This may help explain another seeming paradox - the fact that goods that by survey measures have significant power over price are nonetheless often priced the same as other products of similar type. While perfect competition is one explanation for equal pricing, Cellophane-style constrained-marketpower pricing is equally possible. 
Even absent such evidence, the strong value of brand loyalty across all products provides significant incentives for price discrimination among IP owners. Where IP owners have ways to segment the market between high-value and low-value users by differentiating their products, they often do so. Booksellers charge more money for books when they are first released in hardback than they do later when the book is reprinted in paperback. Apparel manufacturers charge more in some venues than others and discount the price of their clothes and handbags over time as the supply of high-value early adopters is depleted. Movie theaters charge more to patrons who come in the evening than to those who show up for matinees and more to those who watch the same movie in $3 \mathrm{D}$ than to those who don't. And sellers of software, particularly online, charge different prices to different groups. ${ }^{158}$ Price discrimination of this sort affects cross-elasticity of demand because the supplier can identify and isolate the subset of customers who have a low cross-elasticity and charge them higher prices, while maintaining a lower price for the set of customers who might be expected to switch. If there were a way to charge the $72 \%$ of customers who would pay $20 \%$ more a higher price than the $28 \%$ who wouldn't, such a price increase would surely be profitable. And so-at least for that set of customersthe copyrighted or trademarked good is not likely to be put in the same market as alternative products of the same type. Companies that don't have market power in the traditional sense, but who can price discriminate, may nonetheless have power over a subset of their customers.

There are other possible explanations for equal pricing as well. First, prices are often sticky, because people put prices in mental buckets. Raising the price from $\$ 0.99$ to $\$ 1.03$ is likely to have a much more significant effect on consumer behavior than a similar increase that doesn't take the price out of the "less than \$1" category. See, e.g., Gregory Passewitz, Consumer Psychology Towards Price 2 (2003), http://srdc.msstate.edu/trainings/presentations_archive/2003/2003_bst_passewitz.pdf (identifying $\$ 1.00$ as a "major barrier" in consumer purchasing decisions). Second, pricing is costly. Consumers may in fact value every book in a bookstore at a different aggregate level, but determining that level might not be worth it for each book. Even if it is, a third problem is that too many prices, like too much choice in other contexts, can overwhelm consumers and deter them from buying anything. See, e.g., Barry Schwartz, The Paradox of Choice: Why More Is Less (2004). Finally, consumers view pricing at least in part as a moral rather than a merely economic act. They will affirmatively resist a price they consider "unfair" or "discriminatory" even if they value the product enough to justify paying the price. Adidas and the New Zealand All Blacks rugby team found this out when they tried, quite reasonably, to charge more for All Blacks's jerseys in New Zealand than it did in other countries. The resulting outcry cost them both sales and fan loyalty in New Zealand, even though from an economic perspective it should have been entirely unsurprising that New Zealanders valued the jersey more than others. See Jonathan Hutchison, The Price of a Jersey Sets Rugby Fans Against Adidas, N.Y. Times, Aug. 25, 2011, at B3.

For all of these reasons, price differentiation may be smoothed out at the retail level. For example, a retailer will often have an incentive to sell Coke and Pepsi for the same price even if the wholesale cost is greater for one than the other.

158. For discussion of price discrimination in IP, see, for example, Julie E. Cohen, Copyright and the Perfect Curve, 53 Vand. L. Rev. 1799 (2000); Jerry A. Hausman \& Jeffrey K. MacKie-Mason, Price Discrimination and Patent Policy, 19 RAND J. Econ. 253 (1988); Michael J. Meurer, Copyright Law and Price Discrimination, 23 CARDozo L. Rev. 55 (2001). 
In short, the evidence does not support the conclusion that IP rights automatically confer market power. But it does suggest that a surprisingly large number of IP rights do in fact give their owners power over price. Under traditional antitrust principles, those products are not in the same market as the goods that would seem to be their closest competitors.

\section{IMPLICATIONS OF MARKET DEFINITION IN IP CASES}

It is difficult to overstate just how shocking this conclusion ought to be to antitrust lawyers. It is not simply that economists and law professors have been arguing for years that IP rights don't confer market power, ${ }^{159}$ deriding the contrary view as "monopoly phobia." ${ }^{160}$ Nor is it that it was only six years ago the Supreme Court finally overruled decades of Supreme Court precedent saying that IP rights did confer market power. ${ }^{161}$ For even when the law nominally recognized the possibility that IP rights conferred market power, antitrust law never really acted as if it believed they did.

Consider the implications of concluding that Coke (or Harry Potter books or Shell gasoline or Clorox bleach or brand-name pharmaceuticals) really is in an antitrust market by itself. Antitrust law draws sharp distinctions between unilateral conduct, agreements with competitors, and agreements with noncompetitors. Agreements between horizontal competitors to create cartels that restrict price or competition get the harshest condemnation; they are illegal per se. ${ }^{162}$

159. See, e.g., Philip Areeda \& Louis Kaplow, Antitrust Analysis 441 (1988) (suggesting that $80-90 \%$ of all patents may be without any commercial value, much less any market power); 1 Hovenkamp et al., supra note 66, ch. 4; Herbert Hovenkamp, Economics And Federal Antitrust LAW $\S 8.3$, at 219 (1985) ("Many patents confer absolutely no market power on their owners ... . The economic case for 'presuming' sufficient market power . . . is very weak."); F.M. SCHERER, THE ECOnomic Effects of Compulsory Patent Licensing 44-47 (N.Y.U. Grad. Sch. Bus. Admin. Monograph SERIES IN FIN. \& Econ. No. 1977-2, 1977) (explaining that the lack of commercial value of most patents negates the utility of compulsory licensing); Salem M. Katsh et al., Panel Discussion at ABA National Institute on Industrial and Intellectual Property, The Value of Patents and Other Legally Protected Commercial Rights, in 53 AnTitRust L.J. 535, 547 (1985) (according to F.M. Scherer, "[s]tatistical studies suggest that the vast majority of all patents confer very little monopoly power."); William Montgomery, Note, The Presumption of Economic Power for Patented and Copyrighted Products in Tying Arrangements, 85 Colum. L. Rev. 1140, 1156 (1985) ("More often than not, however, a patent or copyright provides little, if any, market power."). Strictly speaking, the economists were right: IP rights don't necessarily confer market power. But it is all too easy to leap from that conclusion to the idea that IP rights don't confer market power. As we have seen, sometimes they do-more frequently than we like to admit and probably more often when we're dealing with litigation-worthy IP rights. For an early recognition of the problem we discuss here, see Ariel Katz, Making Sense of Nonsense: Intellectual Property, Antitrust, and Market Power, 49 Ariz. L. Rev. 837 (2007).

160. Beverly W. Pattishall, Trademarks and the Monopoly Phobia, 50 Mich. L. Rev. 967, 967-68 (1952).

161. Ill. Tool Works Inc. v. Indep. Ink, Inc., 547 U.S. 28, 45-46 (2006) (eliminating the presumption of market power that had been attributed to the tying product in an antitrust case where the tying product was patented). Illinois Tool Works reflected the overwhelming weight of scholarly opinion on the question. See id. at 44 ("[T] he vast majority of academic literature recognizes that a patent does not necessarily confer market power.”). This view has not always been universal, however. See, e.g., Frank J. Hogan, Patent Monopoly, 1 Geo. L.J. 23 (1912).

162. 4A AREEDA \& HovenKamp, supra note 107, II 980. 
Agreements between parties in a buyer-seller relationship (vertical agreements) are treated much more leniently. ${ }^{163}$ And agreements between companies that are not in a competitive relationship at all generally get no antitrust scrutiny. Unilateral conduct is not condemned at all unless the actor is a monopolist. If it is, a number of otherwise legal acts become antitrust problems if they have the purpose or effect of acquiring or maintaining market power. ${ }^{164}$

A world in which individual books and individual brands define their own markets and, hence, confer market power turns that world upside down. To oversimplify, if IP rights define their own markets, everyone is monopolizing and no one is cartelizing. On the one hand, a number of accepted business practices become illegal if the firm that engages in them has market power. For instance, exclusive dealing arrangements in which a party agrees to sell to or buy from only one party, are subject to antitrust's rule of reason. They are illegal if entered into by firms with market power and if they foreclose a "substantial share" of the market. ${ }^{165}$ But if the market is defined not as "novels" or even "fantasy novels" but "Harry Potter books," J.K. Rowling entered into an illegal exclusive dealing arrangement when she allowed only Scholastic to produce and sell her books. So did New Zealand's All Blacks rugby team when they exclusively licensed Adidas to make their jerseys, and so does Coke each time it signs an exclusive distributorship deal. Grants of exclusive franchise territories by McDonald's look like a market allocation scheme if we don't think Burger King competes in the same market. And so on. Antitrust spent the last thirty-five years undoing its rules restricting vertical restraints, ${ }^{166}$ in large part on the theory that it was worth sacrificing "intrabrand competition" among dealers or franchisees in the service of promoting more "interbrand competition." 167 But if interbrand competition doesn't work-if the brands aren't really competing in the same market at all - the last forty years of antitrust history have been a colossal mistake.

Concluding that many IP rights define markets turns a wide array of companies into monopolists, and so in many ways it would dramatically expand the role of antitrust law. But in other respects, it would shrink it. Suppose Pepsi and Coke were to enter into a horizontal market division agreement in which Pepsi agreed to sell only north of the Mason-Dixon Line and Coke agreed to sell only south of that line. If Pepsi and Coke compete in the same product market, that

163. Nominally, vertical agreements are subject to the rule of reason, but in practice they are virtually always held legal. See, e.g., Reeves \& Stucke, supra note 112, at 1549; Schwartz, supra note 137 (applying the rule of reason to sports leagues).

164. See generally 1 HovenKAMP ET AL., supra note 66, ch. 10.

165. See Tampa Elec. Co. v. Nashville Coal Co., 365 U.S. 320, 327 (1961).

166. Reeves \& Stucke, supra note 112, at 1549-50.

167. See, e.g., Cont'1 T.V., Inc. v. GTE Sylvania Inc., 433 U.S. 36, 54-55 (1977) (concluding that interbrand competition between television sets was more important than intrabrand competition because the court assumed that "televisions" were a holistic market); Herbert Hovenkamp, Post-Sale Restraints and Competitive Harm: The First Sale Doctrine in Perspective, 66 N.Y.U. Ann. Surv. Am. L. 487, 488-49 (2011). 
agreement would be illegal per se, just as it would be if they both agreed on the price they would charge. ${ }^{168}$ But if they aren't competitors, traditional antitrust analysis doesn't have much to say about agreements they enter into, any more than it would object to Coke's agreeing with the two of us on the price it might charge. ${ }^{169}$ Similarly, if (as some courts have concluded) brand name drugs are not in the same market as their generic equivalents because the branded drugs command different prices than the generics, an agreement to fix the prices of the branded and generic drugs, or to pay the generic drug company to leave the market, would not seem to be an antitrust problem. ${ }^{170}$ And companies that make one of only two drugs for a particular disease could acquire the other, avoiding competition concerns by arguing that the drugs are differentiated and are prescribed by different doctors in different circumstances. ${ }^{171}$

168. See Palmer v. BRG of Ga., Inc., 498 U.S. 46, 49-50 (1990) (per curiam) (finding "unlawful on its face" a territory-allocation and revenue-sharing agreement between two bar-review companies).

169. It is true that product differentiation does make cartelization harder, see Christopher R. Leslie, Trust, Distrust, and Antitrust, 82 Tex. L. Rev. 515, 579 n.453 (2004), but it surely doesn't make it categorically impossible.

170. To be sure, some courts have (wrongly) reached the conclusion that paying a generic to leave the market is per se legal. See, e.g., In re Ciprofloxacin Hydrochloride Antitrust Litig., 544 F.3d 1323 (Fed. Cir. 2008); In re Tamoxifen Citrate Antitrust Litig., 466 F.3d 187, 212 (2d Cir. 2006). But those decisions have been roundly criticized by the vast majority of scholars in the field. See RoBin FELDMAN, The Role of Science in Law 167 (2009); 1 Hovenkamp et al., supra note 66, § 15.3(C); Roger D. Blair \& Thomas F. Cotter, Are Settlements of Patent Disputes Illegal Per Se?, 47 Antitrust Bull. 491, 534-39 (2002); Jeremy Bulow, The Gaming of Pharmaceutical Patents, 4 InNovation Pol'y \& Econ. 145 (2004); Michael A. Carrier, Unsettling Drug Patent Settlements: A Framework for Presumptive Illegality, 108 Мich. L. Rev. 37, 37-41 (2009); Daniel A. Crane, Exit Payments in Settlement of Patent Infringement Lawsuits: Antitrust Rules and Economic Implications, 54 FLA. L. REv. 747 (2002); Joshua P. Davis, Applying Litigation Economics to Patent Settlements: Why Reverse Payments Should Be Per Se Illegal, 41 Rutgers L.J. 255, 257-58 (2010); Joseph Farrell \& Carl Shapiro, How Strong Are Weak Patents, 98 Am. Econ. Rev. 1347, 1347 (2008); C. Scott Hemphill, Paying for Delay: Pharmaceutical Patent Settlement as a Regulatory Design Problem, 81 N.Y.U. L. Rev. 1553, 1557 (2006); Herbert Hovenkamp et al., Anticompetitive Settlement of Intellectual Property Disputes, 87 MinN. L. Rev. 1719, 1721-22, 1751-63 (2003); Mark A. Lemley \& Carl Shapiro, Probabilistic Patents, 19 J. Econ. PersP. 75 (2005); David W. Opderbeck, Rational Antitrust Policy and Reverse Payment Settlements in Hatch-Waxman Patent Litigation, 98 Geo. L.J. 1303 (2010); Maureen A. O’Rourke \& Joseph F. Brodley, An Incentives Approach to Patent Settlements: A Commentary on Hovenkamp, Janis \& Lemley, 87 Minn. L. Rev. 1767, 1781-82 (2003); Rudolph J.R. Peritz, Three Statutory Regimes at Impasse: Reverse Payments in "Pay-for-Delay" Settlement Agreements between Brand-Name and Generic Drug Companies, in More Common Ground For International Competition Law? (Josef Drexl et al. eds., 2011); Catherine J.K. Sandoval, Pharmaceutical Reverse Payment Settlements: Presumptions, Procedural Burdens, and Covenants Not to Sue Generic Drug Manufacturers, 26 SANTA Clara Computer \& High Tech. L.J. 141, 142 (2009); Carl Shapiro, Antitrust Limits to Patent Settlements, 34 RAND J. ECON. 391, 392 (2003). And, in any event, the decisions are based on the idea that the brand owner held patent rights that gave it the power to prevent generic competition. If the companies aren't competitors, even a drug company that held no patents at all could lawfully pay a generic to stay out of the (different) market for generic versions of the drug.

171. See FTC v. Lundbeck, Inc., 650 F.3d 1236, 1239 (8th Cir. 2011) (upholding that finding by the trial court); $c f$. Delano Farms Co. v. Cal. Table Grape Comm'n, 655 F.3d 1337, 1351-52 (Fed. Cir. 2011) (holding that plaintiff failed to sufficiently allege that Sweet Scarlet variety table grapes were in a separate market from Autumn King table grapes). 
In still other markets the effects may be more ambiguous. In sports leagues, the effect of brand-specific market definition may point in the opposite direction. If an entire sports league is treated as a single entity, it cannot be held liable for conspiring with itself. But if individual teams are separate actors, their agreement to league rules implicates section 1 of the Sherman Act. That is what the Court held in American Needle. ${ }^{172}$ But if the teams are not only separate actors, but also ones that don't compete with each other in a market for merchandise at all, those agreements presumably aren't horizontal restraints on trade. Similarly, antitrust analysis of the Google book search settlement has proceeded on the assumption that "books" (or maybe "out-of-print books") constitute the relevant market. ${ }^{173}$ But if each of the ten million books is its own market, Google presumably isn't creating a horizontal aggregation, though it might face heightened concerns about monopoly, particularly over out-of-print books for which other sources are not available.

In short, if we live in a world in which IP rights regularly confer market power, antitrust law has been doing pretty much everything wrong-finding illegal practices we shouldn't care about and ignoring things that should be quite troubling. ${ }^{174}$ But before we reach that startling conclusion, perhaps it's worth revisiting the concept of market definition itself. For maybe the problem is less that courts have drawn all the wrong conclusions in antitrust cases and more that their market definition tool is broken. We turn to that possibility in Part III.

\section{Rethinking Market Definition in Antitrust}

\section{A. IS ANTITRUST MISCALCULATING MARKETS IN IP CASES?}

One possible explanation for the phenomenon we identified in Part II is that IP markets are different than other goods markets in a way traditional antitrust market definition fails to consider. Market power is a firm's ability to profit by raising price above the competitive level, with the competitive level generally

172. Schwartz, supra note 137 , at $314-15$.

173. See Author's Guild v. Google Inc., 770 F. Supp. 2d 666, 682-83 (S.D.N.Y. 2011). Full disclosure: one of the authors (Lemley) represents Google in this matter.

174. For instance, as Herb Hovenkamp points out, the fact that pharmaceutical companies are willing to pay generics hundreds of millions of dollars not to sell their products seems pretty powerful evidence that the companies think generic sales will have an effect on their market. Herbert Hovenkamp, Response, Markets in IP \& Antitrust, 100 Geo. L.J. 2133 (2012). And although pharmaceutical patent owners don't necessarily drop their prices when generics enter (indeed, the prices may increase), they clearly lose substantial sales to those generics. See Gideon Parchomovsky \& Peter Siegelman, Towards an Integrated Theory of Intellectual Property, 88 VA. L. REv. 1455, 1474-81 (2002). So branded and generic drugs are at least imperfect substitutes: some people are willing to switch from one to the other. But others aren't, allowing brand owners to keep prices high for the subset of consumers who are brand-loyal. The SSNIP test misses this complication because it treats consumers as essentially homogenous. As we discuss in the next Part, that is a mistake. 
defined as marginal cost. ${ }^{175}$ But with IP, the most significant costs are often fixed and fully "sunk" at the time the intellectual property right is developed. The cost to invent a new device or make a new movie doesn't change with the number of copies of the product or movie the creator has produced, and that cost must be paid whether the creator produces anything at all. The marginal cost of selling the invention or creative work is limited to the cost of educating individual buyers and negotiating license agreements, plus whatever it costs to make each incremental version of the product or copy of the work. These costs are often, but not always, quite small in comparison to the costs of initial development.

To illustrate, consider this copyright example. Titanic is a very successful movie. Making Titanic cost roughly $\$ 200$ million, ${ }^{176}$ money that must be recovered if the investment in Titanic is to be profitable. However, once made, the movie can presumably be duplicated onto a DVD for a cost of something like $\$ 2.00$ per copy or downloaded over the Internet for significantly less than that. The only incremental or marginal cost of making a copy is the $\$ 2.00$ or the cost of the server space and bandwidth necessary to stream or download it. But Titanic sells in video stores for $\$ 15.00-\$ 20.00$ per copy. To an antitrust lawyer, this suggests that its owner has very high market power, giving it the ability to charge a price nearly eight times marginal cost. ${ }^{177}$

Perhaps, as some have suggested, marginal cost is the wrong measure of market power in IP cases. ${ }^{178}$ At a price of $\$ 2.00$ per DVD, Titanic might have lost money, and a firm that had contemplated such a price would never have made Titanic in the first place. ${ }^{179}$ A price that merely covers marginal cost in this situation would be insufficient to maintain investment in the market for making movies. To justify being in the movie business, the moviemaker must be compensated not only for the marginal cost of placing a copy of the movie on a DVD but also for the much greater cost of producing and promoting the movie in the first place. So maybe total cost including initial investment, not marginal cost, should be the measure of market power.

Indeed, one might go further. Even if one knew that the revenues from a particular movie exceeded its costs over the movie's marketable lifetime, it would not be clear that the owner of its rights had significant monopoly power

175. Marginal cost is the accepted test for competitive pricing. See 3A AREEDA \& HovenKAMP, supra note 107, II 739. Because it is hard to measure, however, courts often use proxies like average variable cost or "incremental" cost. See, e.g., Brooke Grp. Ltd. v. Brown \& Williamson Tobacco Corp., 509 U.S. 209, 223 (1993).

176. See Box Office/Business For Titanic, InTERnEt Movie DataBase, http://www.imdb.com/title/ $\mathrm{tt} 0120338 /$ business (estimating the cost of producing Titanic at $\$ 200$ million) (last visited Mar. 10, 2012).

177. See 1 Hovenkamp ET AL., supra note 66, ch. 4 (from which this example is taken).

178. Id.

179. While Titanic earned enough money at the box office to become profitable, other movies don't. Because studios don't know ex ante which film will be the next Titanic, they must make some estimate of earnings in deciding how much to invest in making a movie. 
across a range of movies. Moviemaking is a high risk enterprise in which many movies lose money. In order to be profitable in any given year, a movie production company must have profits that exceed losses, and one profitable film may do no more than compensate for two others that lose money. The same thing is true of pharmaceuticals, where most estimates of the cost of drug development include not just the cost of developing the drug that is ultimately sold but also the costs of all the R\&D projects at the company that didn't pan out. ${ }^{180}$ This is even true of trademarks. For example, Ford may market three sedans at a given time- the Fairlane, the Mercury Park Lane, and the Edsel. The Fairlane may make good profits in a particular period while the Mercury returns only marginal profits and the Edsel loses money. Overall, Ford may be a merely profitable firm, not one with supracompetitive profits, if we take into account the failures as well as the successes. On this view, IP rights viewed in context might not confer supracompetitive returns to the company as a whole even though they regularly support prices well in excess of marginal cost for a specific product.

Nonetheless, we don't think market power in IP cases can be dismissed this easily for three reasons. First, and most critically, allocating fixed costs to IP-protected products seems to confuse market definition and market power analysis with the policy desirability of allowing companies to recoup those costs. If two products that consumers find equally attractive have the same price and the same marginal cost, it makes no sense to conclude that they are not in the same market merely because Company $A$ spent more money developing (or marketing) its product than did Company $B$ (or had more failing products). Company $A$ may not be able to compete in the long run because of its investment, but that doesn't mean that it is somehow in a different market than Company $B$. Conversely, the fact that a company may invest in many different movies (or shampoos or other products) over its life doesn't mean that those products compete with each other in the same market; it just means the company is diversifying its risk by taking a chance on many different products. And while we may well want to encourage investments like Company A's by granting IP rights, granting those rights works as an incentive precisely because it does confer on Company $A$ some power over price. To ignore that fact is to ignore the tradeoffs associated with granting IP rights.

Second, even such a sweeping definition of costs wouldn't make the fact that IP rights often confer market power go away. Some IP rights do in fact require a substantial investment of research and development money to generate. But others don't. Sometimes inventors stumble upon very valuable technologies by accident. Songs can be recorded cheaply and written even more cheaply and

180. See, e.g., Matthew Herper, The Truly Staggering Cost of New Drugs, FonBEs, Mar. 12, 2012, at 38 (finding that the average research and development cost per approved prescription drug, accounting for unsuccessful projects, is between $\$ 4$ and $\$ 12$ billion and noting that less than one in ten prescription drugs reaching the human trial stage are ultimately approved). That number is radically higher than other estimates and is almost certainly inflated, but it does indicate the scope of the problem. 
still make millions for their creators. And trademarks in particular don't require much in the way of investment to develop. ${ }^{181}$ The value of a brand is probably positively correlated with the amount spent on marketing, but it seems unlikely that even the most expansive definition of the cost of development ought to include marketing expenses. If it did, then assessment of market definition and market power would become a surreal investigation in which two products that conferred equal profit margins would be treated differently because one company spent more money to promote its brand than did the other (the bigger spender not being treated as a monopolist). Further, to count how much money a company spends on marketing its successes or trying to develop failed products is to fall into a version of the Cellophane Trap. If a company makes a windfall of $\$ 100$ million on a new product, just because it spends that money on research into new products or on advertising doesn't mean that the product was $\$ 100$ million more costly. It just means the company had $\$ 100$ million more to spend.

Finally, even if the technically correct way to measure whether an IP right produces returns above cost would be to compare all development costs for this and related projects with all profits generated by the IP right during its reasonably anticipated marketable lifetime, in practice this is almost always impossible. Not only does it require an enormous amount of information, it imposes serious difficulties if the inquiry must be made (as it often will be) while the product is on the market. Whether the price for Titanic is competitively sufficient, inadequate, or excessive to cover the costs of making that movie and other, less successful movies made by the same studio may not be knowable until all copies of the movie have been sold and all other marketable license rights exhausted. ${ }^{182}$

\section{B. IS MARKET DEFINITION ITSELF A FLAWED ENTERPRISE?}

Perhaps the problem lies not with how market definition is applied to IP cases, but with the enterprise of market definition itself. Antitrust traditionally defines markets in a binary sense-we put a product (and a geographic space) in or out of the market. Then we use mathematical metrics to decide whether a market is too concentrated to allow a merger or sufficiently concentrated that the defendant is a monopolist. One problem is that we are making yes-no decisions in cases that are analog, not digital. It is not the case that a video store

181. See, e.g., Ambrosia Chocolate Co. v. Ambrosia Cake Bakery, 165 F.2d 693, 697 (4th Cir. 1947) ("[A] man or [sic] ordinary intelligence could easily devise a score of valid trade-marks in a short period of time."); Rochelle Cooper Dreyfuss, Expressive Genericity: Trademarks as Language in the Pepsi Generation, 65 Notre Dame L. Rev. 397, 399 (1990) (finding little need for incentives to develop trademarks).

182. That lifetime might be the statutory life of the grant in question or else the shorter time during which sales of further licenses can be profitably made. For example, one patent (say the patent on Lipitor, which expired in 2012) may generate strong royalties over its entire legal life. Another may become obsolete and valueless within a year or two after its issuance. 
three miles away is a potential competitor while another one four miles away is not. Rather, some slightly larger number of consumers will travel three miles than will travel four miles. Similarly, it is not the case that mid-priced four-door sedans all compete perfectly with one another while hatchbacks comprise an entirely separate market with no crossover. And clearly some-but not allcustomers will switch from brand-name drugs to lower-priced generics when they become available. ${ }^{183}$ The current approach to market definition draws an arbitrary line when what we need is a continuum that reflects the partial differentiation of products and differences in the cost and convenience of those products. ${ }^{184}$ That is especially true in IP markets, where the existence of the IP right all but guarantees some amount of product differentiation, making the yes-no framework of classical market definition particularly problematic.

The problem with market definition, however, may be more intractable than just how it is assessed. In a provocative series of articles, Louis Kaplow has argued that the entire enterprise of market definition is fundamentally flawed. ${ }^{185}$ He points out that, to properly define markets, we must have sufficient data to determine how an increase in the price of one good would affect purchases of all other goods sufficiently close to be candidates for inclusion in the same market. Further, we must make a policy judgment regarding how much of a price increase we are willing to tolerate before defining the company that increases its price as a monopolist. But if we have that information, we can determine power over price directly, without ever having to define markets. ${ }^{186}$ Market definition, Kaplow argues, is a fundamentally flawed enterprise because it involves discarding useful information in order to make coarse determinations when we could be making finer ones. ${ }^{187}$

183. See supra notes $125-26$ and accompanying text.

184. See, e.g., Dennis W. Carlton, Market Definition: Use and Abuse, Comp. Pol'y InT'L, Spring 2007, at 3 (arguing that market definition efforts "are at best crude first steps to begin an analysis," the primary use of which is as a threshold to weed out frivolous cases); David S. Evans, Lightening Up on Market Definition, in Research Handbook on the Economics of Antitrust Law 53, 89 (Einer Elhauge ed., 2012) (market definition can play a useful role, but "there is no basis in economics for ... drawing hard market boundaries").

185. See Kaplow, Market Share, supra note 9; Kaplow, Why (Ever), supra note 9. For earlier discussion of the topic, see Richard S. Markovits, Predicting the Competitive Impact of Horizontal Mergers in a Monopolistically Competitive World: A Non-Market-Oriented Proposal and Critique of the Market Definition-Market Share-Market Concentration Approach, 56 TEx. L. Rev. 587 (1978).

186. Kaplow, Why (Ever), supra note 9, at 459-65.

187. A number of antitrust lawyers have challenged Kaplow's assessment. See Gregory J. Werden, Why (Ever) Define Markets? An Answer to Professor Kaplow, available at http://papers.ssrn.com/sol3/ papers.cfm?abstract_id=2004655; see also James A. Keyte \& Kenneth B. Schwartz, "Tally-Ho!'” UPP and the 2010 Horizontal Merger Guidelines, 77 AnTITRUST L.J. 587, 591 n.17 (2011). A full analysis of this debate is beyond the scope of this paper, but we think many of Werden's points actually demonstrate the problems Kaplow identifies. For example, although Werden is correct that we use market definition to do more than simply assess market share, and that it provides a compelling narrative for a jury and a basis for assigning burdens of proof, none of those things are desirable if the market definition is itself a flawed analysis. 
We think Kaplow has a point. Antitrust needs some way to assess the competitive effects of behavior, and that requires some inquiry into who is likely to be affected by that behavior and how. But it probably doesn't need (or want) the kind of formalistic, mathematical framework of the old 1992 Merger Guidelines. The 2010 Merger Guidelines move away from some of the linedrawing of the traditional approach, placing much more emphasis on observed competitive effects-looking, for example, at upward pricing pressure from mergers and companies' responses to actual or threatened entry by a differentiated product. ${ }^{188}$ That is, rather than predicting from numbers how markets will behave, the new guidelines emphasize observable evidence of how conduct affects (or doesn't affect) market outcomes. As a general matter, this is a good thing because it is more realistic. ${ }^{189}$ And it may lead the way towards a good compromise for IP cases, focusing not on artificial constructs nor on special rules designed to make IP market power go away but on the observed reality of how consumers interact with IP rights. ${ }^{190}$

But abandoning market definition, as Kaplow suggests, doesn't mean we can abandon the effort to decide when IP rights confer market power. We may well conclude that branded pharmaceuticals and their generic equivalents aren't in the same market because of the large difference in their prices, but the presence of the generic on a pharmacy shelf next to the branded product surely has some influence on the price and output decisions of the brand owner-more than does, say, the fact that the pharmacy also sells greeting cards. ${ }^{191}$ Some evidence of this is the great lengths to which pharmaceutical patent owners go to avoid having generics enter the market even after their core patents expire, and the fact that when generics do enter they take significant sales away from the brand owner, as well as expanding the market to other customers. ${ }^{192}$ The equilibrium after generic entry may separate into products that are priced differently, but that doesn't mean the introduction of new generics or the prices they set have no effect on branded pharmaceutical pricing or profits. In evaluating efforts by pharmaceutical firms to exclude generic entry, antitrust must take those effects

188. 2010 GuIDELINES, supra note 10, § 2, at 2-6. For discussion, see Louis Kaplow, Market Definition and the Merger Guidelines, 37 Rev. Indus. ORG. 107 (2011) (arguing that the 2010 Guidelines make an incremental step in the right direction but need to go further).

189. See Richard Gilbert \& Daniel Rubinfeld, Revising the Horizontal Merger Guidelines: Lessons from the US and the EU, in Competition Policy and Regulation: Recent Developments in China, Europe, AND the U.S. 262, 575 (M. Faure \& Xinzhu Zhang eds., 2011) (advocating for a focus on "deciding the conditions in which a merger is more or less likely to raise concerns about harm to innovation"); Herbert Hovenkamp, Harm to Competition Under the 2010 Horizontal Merger Guidelines, 37 Rev. Indus. ORG. 3, 4 (2011) (arguing that reducing focus on market definition is a "positive development" compared to "overly technocratic" 1992 Guidelines).

190. See J. Gregory Sidak \& David J. Teece, Dynamic Competition in Antitrust Law, 5 J. CompetiTION L. \& ECON. 581, 583, 585-86 (2009) (explaining that a focus on dynamic competition requires less attention to market definition and market share).

191. We are indebted to Mark Kelman for this point.

192. See supra note 174. 
into account, whether or not it calls the process of doing so "market definition."193

Similarly, deciding where to look for effects on market outcomes requires some implicit judgments about the relatedness of goods that traditional market definition might class as in separate markets. If we're looking at the effects on customers of regular ice cream in Dippin Dots, it doesn't look like there are any; but if you look for effects on buyers of flash-frozen ice cream, you get a different result. Classical market definition requires us to choose one of those markets and to only look for effects there. A more realistic analysis looks for competitive effects in a number of possible places and makes the presence or absence of those effects the critical factor in the analysis.

Courts and agencies have tried various workarounds to classic market definition, perhaps in implicit recognition of the problems with the existing rules. For instance, agencies and courts sometimes define "submarkets" within an antitrust market. ${ }^{194}$ Alternatively, they speak of the "smallest relevant market" that meets the SSNIP test. ${ }^{195}$ The "submarket" concept makes no sense; if a market is a grouping of products that share high cross-elasticity of demand, a subset of that group shouldn't have the power to raise prices without prompting consumers to switch to the other products in the larger market. If a submarket is properly defined, it means the market itself wasn't properly defined. ${ }^{196}$ The fact that courts and agencies fall back on the idea means that they have some implicit understanding that their market definition rules aren't leading them to logical conclusions.

Sometimes courts or agencies simply ignore the implications of market definition. In the pharmaceutical cases, for instance, no one actually believes that pharmaceutical patents and their generic equivalents have no significant effect on each other. We don't let the conclusion of our market definition analysis interfere with our intuition that these two companies are in some sort of competitive relationship.

Eliminating market definition, then, doesn't mean we stop trying to decide how differentiated products relate to each other. That assessment is necessary to any sort of antitrust analysis. And the evidence suggests that IP rights quite often confer significant power over price. That shouldn't mean that different IP-protected products are necessarily segregated into separate markets. But it does mean that we can no longer assume that IP rights have little or no effect on

193. See Hovenkamp, supra note 174, at 2152-53; see also Malcolm B. Coate \& Joseph J. Simons, In Defense of Market Definition, ANTitrust Bull. (forthcoming) (manuscript at i), available at http://ssrn.com/abstract_id=1967208 (arguing that the alternatives to market definition "lack the benchmarks necessary to establish findings of monopoly power").

194. See, e.g., FTC v. Whole Foods Mkts., Inc., 548 F.3d 1028, 1037 (D.C. Cir. 2008) (“A broad market may also contain relevant submarkets which themselves 'constitute product markets for antitrust purposes."” (quoting Brown Shoe Co. v. United States, 370 U.S. 294, 325 (1962))).

195. 2010 GuIDELINES, supra note $10, \S 4.1 .2$, at 10 .

196. See 2B AREedA \& HovenKamp, supra note 107, If 533 ("Speaking of submarkets merely confuses the issue."). 
price and market power. ${ }^{197}$ Consistent with the economic literature on IP and product differentiation, IP rights will often confer significant power over price and purchasing decisions, which means those rights will often tread on territory we think of as reserved for antitrust law. Efforts by courts and scholars to assume away any conflict between IP and antitrust are accordingly misguided. The reality of this conflict doesn't mean antitrust law must always triumph; there are good reasons for IP law to create at least some modest product differentiation. ${ }^{198}$ But it does mean that the conflict cannot be wished away by invoking the mantra that IP and antitrust law serve the same goals. ${ }^{199}$

The problems with market definition also mean that antitrust law must pay more attention to actual competitive effects and less attention to nice numerical formulas in evaluating mergers and anticompetitive conduct. The 2010 Merger Guidelines are an admirable step in the right direction. While they continue to define markets and use the SSNIP test, this approach is merely one among many, and it takes a back seat to an actual analysis of competitive relationships and upward pricing pressure. ${ }^{200}$ We think the Guidelines are right to pay less attention to arbitrarily defined markets and more attention to the actual effects a merger or a licensing practice will have on pricing and output decisions across a range of differentiated products.

\section{LESSONS FOR IP}

In our view, the difficulty courts have experienced with market definition in IP cases stems, at least in part, from their (perhaps intuitive) resistance to relying on the antitrust understanding of markets. The antitrust approach, as we have argued, derives from a classical conception of competition involving undifferentiated goods where producers compete solely on price and quality. But markets for goods encumbered by IP rights are different: these goods are, by definition, differentiated, either in terms of some product feature or because of the product's branding. This product differentiation isn't unequivocally bad, of course. Indeed, markets characterized by differentiated products often give consumers choices and that can enhance consumer welfare. ${ }^{201}$ And in some

197. But see Sheridan v. Marathon Petroleum Co., 530 F.3d 590, 595 (7th Cir. 2008) (dismissing the "slight monopoly power" trademarks enable). Desai and Waller ably explain why this back-of-the-hand rejection of the power IP rights confer over price won't suffice. Desai \& Waller, supra note 119, at $1473-76$.

198. Yoo, Copyright and Product Differentiation, supra note 103.

199. See Mark A. Lemley, Industry-Specific Antitrust Policy for Innovation, 2011 Colum. Bus. L. REv. 637 (2011).

200. For explanation and a defense of this move, see Carl Shapiro, The 2010 Horizontal Merger Guidelines: From Hedgehog to Fox in Forty Years, 77 AnTitrust L.J. 49 (2010).

201. See Yoo, Copyright and Product Differentiation, supra note 103; see also Apostolos Chronopoulos, Trade Dress Rights as Instruments of Monopolistic Competition: Towards a Rejuvenation of the Misappropriation Doctrine in Unfair Competition Law and a Property Theory of Trademarks, 16 Marq. Intell. Prop. L. Rev. 119, 130-36 (2012) (arguing that strong rights in product design and limits on functionality defenses will spur competition by increasing product variety). 
cases we need to confer some power over price on IP owners as part of a government policy to drive investment in innovation. ${ }^{202}$ But these benefits come at a cost to the extent differentiation insulates some IP owners from competition. And we think the evidence suggests that this cost can be significant: contrary to some suggestions, entry of additional differentiated products in response to supracompetitive pricing often does not undermine pricing power precisely because IP rights guarantee those new entrants will only be imperfect substitutes. $^{203}$

This is not to say, however, that all IP rights create market power that antitrust should care about, or even that all IP rights have the same effect on substitution. Indeed, we suspect that the effects of an IP right are likely to be quite different in a variety of respects. They may vary by IP right (patent vs. copyright vs. trademark) because each of those rights will attach, generally speaking, to different features. They may vary by the type of product or service at issue. And they may vary by industry, even perhaps with respect to the same type of product or service. The general point is that the competitive costs of IP rights vary with the extent to which they enable the owners of those rights to exclude close substitutes, and courts should therefore conceive of competition in the IP space in terms of the quality of available substitutes. Rather than considering whether a particular product is in the relevant market, courts must at a minimum think of competition as existing along a spectrum. The further away one product is from another on that spectrum (that is, the more imperfect it is as a substitute), the less we can see the product as effectively constraining the price of the first product or offering a realistic alternative to many consumers. Indeed, there may be multiple dimensions to the differentiation, including price, quality, and (for IP goods) brand association.

Conceiving of competition in this way does not obviate the need for a policy judgment, of course, any more than avoiding explicit market definition in antitrust allowed us to escape a focus on competitive effects. For even if courts take the approach we suggest and focus on the relative closeness of available substitutes, determining when the substitutes are sufficiently close that we can count them as competing goods entails a judgment about how much competi-

202. This is the basic public goods story at the heart of IP law. For discussion, see Mark A. Lemley, The Economics of Improvement in Intellectual Property Law, 75 TEx. L. REv. 989, 993-1000 (1997).

203. Yoo argues, for example, that the market for copyrighted works is best seen through a product differentiation lens and that there is less reason to be concerned about the competitive effects of copyright so long as it is possible for substitutes to enter. Yoo, Copyright and Product Differentiation, supra note 103. We agree with Yoo that product differentiation is a better way of viewing markets for copyrighted works and, indeed, IP markets generally. But we have less faith that entry of new expressive works in the same genre will necessarily limit market power, just as we think entry of new brands in the luxury handbag market is unlikely to bring luxury handbag prices down anywhere near marginal cost. And, as we note below, how effective entry will be is itself a function of the breadth of legal rights that limit that entry. Cf. Heald, supra note 149 (showing that creation of different copyrighted works does not constrain price as effectively as being able to compete to sell the same work). 
tion we want in this space. And such a policy judgment must be made at two levels: (1) at the level of specific cases, where courts must define a market in order to determine, for example, the amount of damages to award a patent plaintiff; and (2) at the rule level-where courts and/or Congress affect the extent of IP-based product differentiation by determining the scope of IP rights generally.

At the level of specific cases, we think that IP law can learn something from a more flexible antitrust market definition, despite the many flaws in antitrust's approach. Because courts in antitrust cases use market definition for the ultimate purpose of assessing market power, and because those courts treat market power differently in different contexts, market definition itself tends to look different in different antitrust contexts. Market definition, in other words, has many masters in antitrust, just as it does in IP. Hence, although IP courts should think more coherently about the nature of competition between IP-protected products, they might well make different policy judgments in different circumstances about when products are sufficiently close that they raise competitive concerns. Some of the contexts we identified in which market definition arises in IP cases reflect courts' attempts to limit the competitive consequences of IP rights. And the extent to which courts ought to be concerned about those competitive costs depends on the importance of the type of protection the plaintiff in that case seeks relative to the purposes of the IP doctrine at issue. In our view, for example, the benefits of trademark protection for product design features are quite low-consumers are likely to have several other indicators by which they can identify the source of the product at issue (packaging, brand names, etc.), so protection of the product design itself often has relatively little marginal source-identifying value. Thus, we think it would be entirely appropriate for courts to define markets narrowly in functionality cases where competitive need is relevant, so that close substitutes would need to be available to avoid a finding of functionality. Likewise, if we were confident that patent law's eligibility doctrines adequately distinguished inventions that truly deserved a patent from more trivial innovations, then courts in patent infringement cases might also be justified in defining markets narrowly there for the purpose of ensuring adequate compensation.

The general point is that the methodology courts use to define the relevant market is distinct from the purpose for which that market definition is made. In terms of methodology, we think courts need to focus on the quality of available substitutes in the market, defined by consumer demand and not merely (and in some cases perhaps not at all) in terms of function. How close those substitutes need to be for a court to declare them to be in the same market depends on the purpose for which the court is engaged in market definition. And because those purposes differ, the policy judgment about when alternatives are sufficiently close to consider them in the same market might differ as well.

At the more general level of the appropriate scope of IP rights, the question is when an IP right creates or enables so much differentiation that the costs of IP 
protection are too high to justify their benefits. Resolving that question requires policymakers to ask how much market power we want an IP owner to have, and that determination is bound up with the policy justifications of IP rights in the first place. If, for example, we believe patent rights are important to create incentives to invent (or to commercialize), then patent rights should be structured to enable sufficient differentiation to provide the incentive, but no more. ${ }^{204}$ Likewise, if trademark law's goal is to enable consumers to rely on trademarks when deciding what goods or services to buy, then we may have to tolerate some brand-based differentiation for a trademark to serve its function, even if differentiation is itself not trademark law's goal.

We don't purport to answer the question of "how much market power is sufficient" in this Article. That is the collective subject of most IP scholarship. We have articulated views on particular facets of that question in the past, often (but not always) suggesting that IP rights today are unduly broad. ${ }^{205}$ But you don't need to agree with that for our argument here to work. Our point is that IP rights are not free. Though IP and antitrust doctrine and scholarship have minimized the presence of a conflict between the two in recent decades, IP rights do in fact confer significant power over price in a surprising array of cases. The IP-antitrust conflict, then, is more significant than most people acknowledge.

If we wish to restrict the extent to which IP rights confer market power, and therefore minimize the range of conflict between the doctrines, we should focus on IP doctrines through which differentiation could be reduced. Those are the most efficient ways to reduce the harm caused by IP while still protecting IP rights. Put differently, to reduce the competitive costs of IP rights we can adjust doctrinal rules for the purpose of enabling closer substitutes. ${ }^{206}$ In this Part, we identify some doctrinal contexts we see as especially conducive to tailoring for the purpose of enabling closer substitution. ${ }^{207}$

\section{A. COPYRIGHT}

\section{Substantial Similarity and the Derivative Work Right}

In the copyright area, courts could use a number of doctrinal levers to lessen the distance between the copyrighted work and available substitutes. First,

204. Cf. Michael Abramowicz \& John F. Duffy, The Inducement Standard of Patentability, 120 YALE L.J. 1590 (2011) (arguing that only inventions for which a patent was necessary to induce the invention should be patentable).

205. Among many others, see Mark A. Lemley \& Mark McKenna, Irrelevant Confusion, 62 STAN. L. Rev. 413 (2010); Lemley \& McKenna, supra note 46.

206. An alternative approach would apply antitrust law in cases involving market power, even though that power was conferred by an IP right. As we noted in the previous two Parts, that approach is likely to lead to some perverse results given the current structure of antitrust law, and we do not favor it.

207. Again, you don't have to agree with us that IP rights ought to be tailored to reduce differentiation. Even if you think IP rights should enable greater differentiation, these doctrines are especially conducive to achieving that end too, though they would need to be adjusted in the opposite direction. 
courts could require much greater similarity between a plaintiff's and defendant's works in order for the defendant's work to be considered "substantially similar" and therefore infringing. ${ }^{208}$ As things stand, although a plaintiff must prove that the defendant's work is substantially similar, the meaning of "substantial" has broadened significantly over time. Whereas the defendant's work once would have needed to be virtually identical to the plaintiff's in order to be considered an infringement, ${ }^{209}$ courts now find infringement based on fragmented literal similarity ${ }^{210}$ and nonliteral or pattern similarity, including similarities in plot and/or characters. ${ }^{211}$ As a consequence, a copyright owner now can block works that are less similar to their own, meaning they can force third parties to produce less perfect substitutes. Courts could reduce the competitive costs of copyright, then, by requiring greater similarity to prove infringement.

Likewise, the derivative work right currently enables copyright owners to create further space around their own work by excluding related or follow-on works that might be closer substitutes for the copyright owner's own work than

208. The standard of similarity is quite lenient. See, e.g., Roth Greeting Cards v. United Card Co., 429 F.2d 1106, 1110 (9th Cir. 1970); Peter Pan Fabrics v. Martin Weiner Corp., 274 F.2d 487, 489 (2d Cir. 1960); Arnstein v. Porter, 154 F.2d 464, 468 (2d Cir. 1946). For discussion and criticism, see Mark A. Lemley, Our Bizarre System For Proving Copyright Infringement, 57 J. Copyright Soc'y 719 (2010).

209. Neither translations nor "fair abridgments," for example, were considered infringing. See, e.g., Stowe v. Thomas, 23 F. Cas. 201, 208 (C.C.E.D. Pa. 1853) (finding that an unauthorized translation of Uncle Tom's Cabin from English to German did not infringe copyright); Sayre v. Moore, (1785) 1 East 361 (K.B.) (holding defendant's improvements on a copyrighted nautical chart might be sufficient to avoid infringement); Gyles v. Wilcox, (1740) 26 Eng. Rep. 489 (Ch.), 490, 2 Atk. 141, 143 (finding that abridgment of copyrighted volume of crown law was not infringing).

210. See 4 Melville B. Nimmer \& David Nimmer, Nimmer On Copyright § 13.03[A][2] (2011). In general, for fragments of a work to be significant enough to constitute infringement, the fragments must be qualitatively important to the work and not simply random isolated bits. See Harper \& Row Publishers, Inc. v. Nation Enters., 471 U.S. 539, 565 (1985) (finding infringement based on verbatim copying of 300 to 400 words from book manuscript, where excerpts took the "heart" of the book); see also Murray Hill Publ'ns, Inc. v. ABC Commc'ns, Inc., 264 F.3d 622, 633 (6th Cir. 2001) (noting that, to constitute infringement, a single line taken from a protected work would have to be "an integral part" of that work rather than "merely an incidental part of the background" and, by analogy, as "readily recognizable' in terms of its relationship ... as 'E.T. phone home' is to its movie source" (citations omitted)); Baxter v. MCA, Inc., 812 F.2d 421, 425 (9th Cir. 1987) (citing Heim v. Universal Pictures Co., 154 F.2d 480, 488 (2nd Cir. 1946) for the proposition that a "single brief phrase so idiosyncratic as to preclude coincidence might suffice to show copying"). This trend was taken to the extreme in some music cases. See, e.g., Robertson v. Batten, Barton, Durstine \& Osborn, Inc., 146 F. Supp. 795, 798 (S.D. Cal. 1956) (finding infringement based on copying of two bars of music). And some courts in digital sampling cases have rejected any notion that the amount taken might be de minimus and therefore noninfringing. See, e.g., Bridgeport Music, Inc. v. Dimension Films, 410 F.3d 792, 801-02 (6th Cir. 2005).

211. Universal Pictures Co. v. Harold Lloyd Corp., 162 F.2d 354, 360 (9th Cir. 1947) (noting that an "infringement is not confined to literal and exact repetition or reproduction; it includes also the various modes in which the matter of any work may be adopted, imitated, transferred, or reproduced, with more or less colorable alterations to disguise the piracy" (internal quotation marks and citations omitted)); Nichols v. Universal Pictures Corp., 45 F.2d 119, 121 (2d Cir. 1930) ("[W]e do not doubt that two plays may correspond in plot closely enough for infringement."). 
would be unrelated third-party works. The right, therefore, forces third parties to market more imperfect substitutes than they might if they were able to build more directly on the copyrighted work. We could decrease copyright owners' power here by significantly curtailing or eliminating the derivative work right, thereby allowing better substitutes in the market. To put it more concretely, if consumers do not regard Stephen King novels as good substitutes for a new Harry Potter book, then we would better reduce the market power of Harry Potter books by weakening the derivative work right and allowing new Harry Potter-related works in at least some contexts.

The economics of derivative rights are more complex, however, than the economics of substantial similarity. Whereas substantial similarity affects how close a substitute a defendant can make, in many cases derivative works are complements rather than substitutes for the original work, as the derivative works are frequently directed at different markets. A Harry Potter encyclopedia doesn't substitute for sales of the series; it is likely useful only to those who have already read the series. ${ }^{212}$ We may or may not want to give J.K. Rowling control over such a complement, but it doesn't compete with the original in any meaningful way. By contrast, other derivative works might serve as both complements (or other noncompeting goods) and substitutes. Translations expand the market to reach those who speak a different language, but the bilingual might choose the French version of Muriel Barbery's "The Elegance of the Hedgehog" over the English one. For the latter, the translations are substitutes. Similarly, movie versions of books are complements for those who want to read the book and then see the movie, but substitutes for those who opt for one but not the other. Finally, even when a derivative work is clearly a complement for some consumers (those who read the Harry Potter books and then also want to see the movie), it may be that this kind of complement is also a better substitute for the original than some other type of work. Some consumers, for example, might rather watch the Harry Potter movies in place of the Harry Potter books than switch to a Stephen King novel. This doesn't mean Harry Potter movies are particularly good substitutes for the book, only that Stephen King novels, or whatever else is the next best substitute for Harry Potter books, are comparatively worse substitutes.

Depending on how frequently the last situation arises, where a derivative work is both a complement and a better substitute than the next best substitute in the same medium as the original, our analysis might have a surprising implication: if we are concerned only with market power and substitution, we might want to focus more on limiting the scope of the copying right than on restricting the derivative works right. Among derivative works, we might care more about controlling power over that subset of works likely to serve as a

212. Warner Bros. Entm't Inc. v. RDR Books, 575 F. Supp. 2d 513, 550 (S.D.N.Y. 2008) (noting the lack of substititution but finding no fair use). 
substitute for the existing work, rather than derivatives that expand into a new market or act as complements to the original work. This may seem counterintuitive; the case for giving a copyright owner control over derivative works is generally regarded as weaker than the case for preventing copying. ${ }^{213}$ And it may be that there is no need for incentives from derivative works to encourage creation. But from the perspective of market power and, hence, the IP-antitrust conflict, it may be that the breadth of the substantial similarity doctrine is doing more to give copyright owners market power than the derivative works right.

\section{Fair Use}

As we noted above, the fair use doctrine is directly concerned with market substitution. The all-important fourth factor of the fair use analysis asks whether the defendant's use has a market effect on the plaintiff. In essence, that privileges uses that don't substitute for the copyrighted work but allows copyright owners to control uses that do substitute.

If we wanted to reduce the market power of copyright owners, one way to do so would be to refine this analysis. Sometimes a defendant's product harms the market for the copyrighted work because it is the copyrighted elements that make the defendant's work desirable. If people want to buy my review of Gerald Ford's autobiography only because of the words it takes from that autobiography, the fact that I have added my own words (and hence "transformed" the original) is irrelevant. ${ }^{214}$ But at other times the defendant's work is substituting for the original, causing market harm, but the market harm results not from the copyrighted work but from the defendant's new expression. If people buy my rap song in preference to the song from which I sampled not because I sampled that song but because mine is better, that market harm is not attributable to the copyright infringement in any meaningful sense. ${ }^{215}$ Similarly, if it is the unprotectable elements of the copyright owner's work that make my copy desirable, proof of substitution should not preclude a finding of fair use..$^{216}$

Fair use, then, could refine its focus on market harm by imposing a causation requirement of sorts. Market substitution should counsel against a finding of fair use only if the market-substituting effect can be traced to the protectable elements of the copyrighted work.

213. 2 Nimmer \& Nimmer, supra note 210, § 8.09[A]; cf. Paul Goldstein, Derivative Rights and Derivative Works in Copyright, 30 J. COPYRIGHT SOC'y 209 (1982) (defending the derivative works doctrine while acknowledging challenges to it).

214. Harper \& Row, 471 U.S. at 566-69.

215. Cf. Campbell v. Acuff-Rose Music, Inc., 510 U.S. 569, 592-93 (1994) (discussing competition in the market for rap derivatives).

216. This was arguably the court's error in American Geophysical Union v. Texaco Inc., 60 F.3d 913 , 931 (2d Cir. 1994), which found liability even though defendants were interested in copying plaintiff's journal articles for the ideas they contained, not for their copyrightable expression. 


\section{B. TRADEMARK}

\section{Mark Similarity}

A number of scholars, including us, have argued recently that trademark rights should be narrower and more certain in scope. ${ }^{217}$ In large measure, these calls have focused on the requisite similarity of goods - the range of goods or services against which a mark owner could assert its rights. And rights could be narrowed by requiring that the defendant's goods or services be highly similar, or even identical, to the plaintiff's. ${ }^{218}$ But if our goal is to reduce the differentiation afforded by a trademark and make other products better substitutes, then focusing on the closeness of the goods with which the marks are used is only a part of the story. What we should want at least as much is to make more available the differentiating features, which in the trademark context means the marks themselves. We should, in other words, want to allow other parties to get closer to the claimed trademark. One means of accomplishing this in the trade dress context is a robust functionality doctrine, which would prevent parties from claiming certain features as trademarks at all. But in the broad range of cases, the best way to accomplish this would be for courts to put significant weight on the similarity of the marks factor of the likelihood of confusion test, requiring as a necessary condition of liability that the defendant's mark be extremely similar (if not identical) to the plaintiff's claimed mark. We think this may well be particularly important in the trade dress context, both because trade dress is often less clearly defined and because in many cases product packaging or design elements may be the most effective way to communicate that one's product competes with another known product.

As we noted above, how much we want to limit the differentiation enabled by IP rights generally is a question bound up with the policy justifications of various forms of IP. And in the trademark context it may be that some amount of product differentiation is inevitably the byproduct of protection. But we think current law is nowhere near the point at which we need to be concerned about cutting back too far on trademark rights such that consumers are exposed to uses that would cause material confusion. Courts have found marks to be confusingly similar even if they seem to have very little in common, often, though not exclusively, in cases where the mark the plaintiff claims was infringed was only one aspect of the defendant's overall branding. ${ }^{219}$ Failing to

217. See, e.g., Dogan \& Lemley, supra note 120; Lemley \& McKenna, Irrelevant Confusion, supra note 205; Mark P. McKenna, Testing Modern Trademark Law's Theory of Harm, 95 IowA L. Rev. 63 (2009).

218. Doctrinally this could be accomplished by putting much more weight on the similarity of the goods factor in the multifactor likelihood-of-confusion tests that courts use to determine infringement.

219. See, e.g., Maker's Mark Distillery, Inc. v. Diageo N. Am., Inc., 703 F. Supp. 2d 671, 696-97 (W.D. Ky. 2010) (finding likelihood of confusion regarding association when defendant used similar red dripping wax seal but a different brand name for its tequila), aff'd, No. 10-5508, 2012 WL 1605755 (6th Cir. May 9, 2012); Sara Lee Corp. v. Kayser-Roth Corp., No. 6:92-cv-00460, 1992 WL 436279, at *23-*25 (M.D.N.C. Nov. 3, 1992) (granting injunction against defendant's use of confusingly similar 
require a high degree of similarity broadens the scope of the trademark, making it less likely that a competitor can either evoke a mark for purposes of comparison or even communicate clearly that it views itself as in the same market as a leading brand. ${ }^{220}$ There are reasons to impose those limits if the alternative is that consumers are deceived in ways that might affect their purchasing decisions, but too often courts seem to impose those limits-and accordingly raise a trademark owner's power over price—even when confusion is unlikely.

\section{Sponsorship or Affiliation Confusion and Dilution}

In some cases trademarks serve as differentiating features simply because they are serving the function of a trademark, giving consumers information about the nature of the goods with which the mark is used. The Coca-Cola mark, for example, helps differentiate Coca-Cola from Pepsi or other drinks by telling consumers about the taste of the beverage bearing that mark. But this is hardly the only, or even the primary, way trademarks enable differentiation. In many cases brand meaning is not tied to any particular characteristics of the actual product but merely reflects people's associations with the brand itself. The mark, in other words, doesn't merely reflect differences in the products; in a significant way, it is the difference. So understood, the way to decrease differentiation (to enable better substitutes) is to decrease mark owners' ability to control that brand meaning.

Under current law, mark owners protect this brand meaning primarily through broad sponsorship or affiliation claims in contexts far beyond those in which consumers could reasonably believe the mark owner was responsible for the quality of the defendants' goods or services. ${ }^{221}$ But they also protect this meaning more directly through dilution claims, which are intended to protect the singularity of a mark's meaning. ${ }^{222}$ To reduce brand owners' ability to differentiate along this brand meaning dimension, both of these types of claims could be eliminated or at least substantially limited.

Like the derivative works right in copyright, the analysis here is complicated by uncertainty as to whether the defendants in these cases are offering substitute

marks despite dissimilar package shape, which was the only inherently distinctive element of plaintiff's trade dress); Source Perrier, S.A. v. Waters of Saratoga Springs, Inc., No. 81-cv-0178, 1982 U.S. Dist. LEXIS 9981, at *8 (S.D.N.Y. Dec. 9, 1982) (explaining that the "fact that [defendant] placed a different label on its confusingly similar bottle does not alter" result of confusion and trade dress infringement).

In the registration context, courts sometimes find marks similar based solely on similarity in meaning. See Hancock v. Am. Steel \& Wire Co. of N.J., 203 F.2d 737, 740 (C.C.P.A. 1953) (holding "Hurricane" confusingly similar to "Cyclone" for fencing materials).

220. Cases involving private label goods have gotten this right in our view. See, e.g., McNeil Nutritionals, LLC v. Heartland Sweeteners, LLC, 511 F.3d 350 (3d Cir. 2007) (contrasting noninfringing and infringing store-brand packaging); Conopco, Inc. v. May Dep't Stores Co., 46 F.3d 1556 (Fed. Cir. 1994). But there is no reason why the lessons of these cases should be confined to that context.

221. Lemley \& McKenna, Irrelevant Confusion, supra note 205.

222. See 15 U.S.C. $§ 1125$ (c) (2006). 
products at all. There may be, as we have argued elsewhere, little reason to give trademark owners control over marks in markets they are unlikely ever to enter. ${ }^{223}$ But in most cases, where the defendant's goods are sufficiently far afield from the plaintiff's, that control is unlikely to confer market power in any significant sense. From the perspective of the IP-antitrust conflict, then, the most troubling applications of the sponsorship/affiliation and dilution cases are not those that occur in remote markets, but those that affect actual or likely substitutes. When a trademark owner uses dilution to make up for holes in its likelihood-of-confusion case against a competitor, for instance, it is interfering with expected market competition that trademark law ought to allow. ${ }^{224}$ Thus, it is a serious problem that dilution claims in practice turn out overwhelmingly to be redundant of broad sponsorship or affiliation claims. ${ }^{225}$ Similarly, when a trademark owner asserts a dilution claim against a reseller of its goods or an infringement claim against a supplier of service for its branded cars, ${ }^{226}$ that suit has real costs to competition because it is targeting a lawful substitute for the trademark owner's goods or services.

There is one further complication that deserves mention here. In some cases - most likely, in our view, in the context of luxury brands-it may be that it is access to a mark that itself defines the relevant market. For example,

223. Lemley \& McKenna, supra note 46.

224. See Nabisco, Inc. v. PF Brands, 191 F.3d 208, 221-23 (2d Cir. 1999) (precluding Nabisco competitor from selling fish-shaped crackers despite the absence of consumer confusion).

225. Barton Beebe, The Continuing Debacle of U.S. Antidilution Law: Evidence from the First Year of Trademark Dilution Revision Act Case Law, 24 Santa Clara Computer \& High Tech. L.J. 449 (2008). A few state dilution statutes have made it a requirement that the defendant's good be noncompetitive, and our analysis suggests that, to whatever extent dilution claims are justified, these limitations are good ones if the goal is to reduce market power. The Illinois dilution statute, for example, 765 Ill. Comp. Stat. 1036/65 (1998), does not apply to competitors. See Thomas \& Betts Corp. v. Panduit Corp., 935 F. Supp. 1399, 1419 (N.D. Ill. 1996), rev'd in part on other grounds, 138 F.3d 277 (7th Cir. 1998) ("The Illinois Anti-Dilution act does not apply to competitors." (citing EZ Loader Boat Trailers, Inc. v. Cox Trailers, Inc., 746 F.2d 375, 380 (7th Cir. 1984))).

226. See Ga. Pac. Consumer Prods., LP v. Von Drehle Corp., 618 F.3d 441 (4th Cir. 2010) (denying summary judgment because of fact questions about whether restroom visitors would be confused as to source of paper toweling dispensed from manufacturer's branded dispensers when dispensers were loaded with competitor's generic paper toweling); Bandag, Inc. v. Al Bolser's Tire Stores, Inc., 750 F.2d 903 (Fed. Cir. 1984) (holding that dealer's use of plaintiff's mark infringed because its telephone directory advertising falsely suggested that dealer was a franchisee of the plaintiff); Harley-Davidson Motor Co. v. Iron Eagle of Cent. Fla., Inc., 973 F. Supp. 1421, 1425 (M.D. Fla. 1997) (holding that seller of replacement parts for Harley-Davidson motorcycles infringed because its use of the marks was likely to confuse customers into thinking that the shop was an authorized dealer).

Even when courts reject mark owners' claims in these cases, they leave open the possibility of many more suits by making the issue of fair use depend on whether the use causes confusion. See, e.g., Scott Fetzer Co. v. House of Vacuums Inc., 381 F.3d 477, 484 (5th Cir. 2004) (finding that a dealer in Kirby vacuums could use the Kirby mark in a Yellow Pages advertisement, but only if the ad did not cause confusion: "[i]ndependent dealers and repair shops may use a mark to advertise truthfully that they sell or repair certain branded products so long as the advertisement does not suggest affiliation or endorsement by the markholder"); see also Rosetta Stone Ltd. v. Google Inc., 676 F.3d 144 (4th Cir. 2012) (reversing grant of summary judgment for Google and concluding that nominative use depends on analysis of the likelihood of consumer confusion). 
marketing literature makes clear that "luxury" sometimes serves as a superordinate category for consumers, such that luxury watches might compete more with luxury handbags than with nonluxury watches. And this may well extend to individual brands in some cases: Louis Vuitton watches might be better substitutes for Louis Vuitton handbags than Gap handbags are for Louis Vuitton handbags. Where that is true, the idea of defining markets in relation to product categories doesn't make sense; the relevant market is more meaningfully defined by the brand itself than by traditional product categories. In those cases we cannot be comforted about the competitive effects of dilution protection even if the claims were confined to different goods, because it would not be the difference in goods that matters for purposes of market power.

\section{Comparative and Keyword Advertising}

To the extent nontrademark characteristics of products or services make them good substitutes for the plaintiff's products, comparative advertising can be an effective way of constraining market power by bringing those potential substitutes to the attention of consumers. And trademark law has long allowed parties to use the trademarks of their competitors in order to enable them to draw attention to the substitutability of their products. ${ }^{227}$ The difficulty is that courts have articulated the comparative advertising defense in ways that make it both less sure and less predictable because they have always attached a caveat that the defendant's use cannot cause confusion. ${ }^{228}$ Given the breadth of modern confusion doctrine, this is an important caveat-where the plaintiff can argue that the use causes initial interest confusion, even if entirely accurate, competitors must be willing to litigate, even in cases in which they are ultimately vindicated.

The uncertainty of the defense is compounded by the fact that plaintiffs of late have used the advent of new technology that enables comparative advertising as a reason to try to get courts to restrict the ability of competitors to engage in comparative ads. Particularly concerning are cases in which plaintiffs assert trademark claims against intermediaries, like search engines, or even against advertisers themselves - despite the fact that the actual advertisement at issue is not even alleged to be false-claiming that the simple fact of using the plaintiff's mark as a keyword or as part of the text (which might allow it to turn up in response to an Internet search) is itself enough to cause confusion,

227. See, e.g., Smith v. Chanel, Inc., 402 F.2d 562, 567 (9th Cir. 1968); see also Hypertherm, Inc. v. Precision Prods., Inc., 832 F.2d 697, 701 (1st Cir. 1987) (holding that "an 'imitator may use in a truthful way an originator's trademark when advertising that the imitator's product is a copy,' so long as no confusion as to the source is likely to result" (quoting Calvin Klein Cosmetics Corp. v. Lenox Labs., Inc., 815 F.2d 500, 503 (8th Cir. 1987))).

228. See 4 McCARTHY, supra note $48, \S 25: 52$ (" $[\mathrm{I}] \mathrm{t}$ is neither trademark infringement nor unfair competition to truthfully compare competing products in advertising, and in doing so, to identify by trademark, the competitor's goods. However, such comparative advertising will not be permitted if it is likely to confuse buyers as to exactly what they are getting."). 
thereby $^{229}$ — disqualifying it from being considered comparative advertising. ${ }^{230}$ Even though advertisers and search engines ultimately have prevailed in most of these cases, generally it has only been after litigation on the likelihood of confusion issue. ${ }^{231}$

Our analysis provides a strong defense for comparative advertising and suggests that recent potential narrowing of the defense is a mistake from the standpoint of concerns about substitution. To the extent other parties' goods or services can serve as substitutes, trademark law should make it easy for those parties to bring their goods to consumers' attention.

\section{THE SCOPE OF PATENT RIGHTS}

The scope of patent rights is a function of the language of the patent claims. Accordingly, any effort to modulate the market power conferred by a patent needs to start with the doctrines of claim construction and infringement. As a general matter, application of those doctrines is case-specific: much turns on the particular words chosen by the patentee and what the court construes those words to mean. But precisely because the focus is on the words chosen by the patent lawyers rather than on what the patentee actually built, patentees have been able to obtain patents that cover broad swaths of conceptual space.

One reason patents are often read broadly is that patent lawyers frequently claim their inventions in functional terms. Rather than limiting the patent to a particular device, patentees claim any device that performs a particular function. This will often, though not always, coincide with market power because control over a particular function may make the development of an effective substitute impossible.

Broad functional claiming was popular a century ago, but courts struck down those claims because they were not tied to particular machine implementations. $^{232}$ In the Patent Act of 1952, Congress allowed claim elements to be written in functional language but provided that those claims did not cover any means for performing the specified function, just the implementations actually

229. There may be other cases in which the claim against an advertiser is based on false or misleading statements within the text of the ads themselves. To the extent the actionable confusion in those other cases is caused by the nature of the use within the ad, the cases are less objectionable, though they still implicate the concern that comparative advertising is not really a defense separate from likelihood of confusion.

230. See, e.g., Network Automation, Inc. v. Advanced Sys. Concepts, Inc., 638 F.3d 1137 (9th Cir. 2011) (finding no likelihood of confusion); Rescuecom Corp. v. Google Inc., 562 F.3d 123 (2d Cir. 2009) (stating that the keyword advertising claim could not be decided on a motion to dismiss because it depended on evidence of confusion). Full disclosure: one of us (Lemley) represented Google in the Rescuecom matter.

231. See, e.g., Rescuecom, 562 F.3d at 123. Rescuecom abandoned its case on remand during discovery. For another case, see GEICO v. Google Inc., No. 1:04CV507, 2005 WL 1903128 (E.D. Va., Aug. 8, 2005) (Google prevailed on keyword advertising claim at trial). In full disclosure, one of us (Lemley) represented Google in the GEICO matter.

232. See, e.g., Holland Furniture Co. v. Perkins Glue Co., 277 U.S. 245, $256-57$ (1928). 
disclosed in the specification and equivalents thereof. ${ }^{233}$ Nonetheless, functional claiming outside the scope of section 112 persists, particularly in the software industry. Software and Internet patentees can get around functional claiming restrictions by claiming computer hardware elements programmed to perform particular functions. Because the precise hardware chosen is essentially irrelevant to the invention, these hardware claim elements provide no real limit on the scope of the claim, but they take it outside the language of section $112 .{ }^{234}$ One way to limit the reach of patent claims, especially in software, is to take seriously the old idea that functional claiming is not permitted and to limit the patentee to what she actually invented or equivalents thereof. ${ }^{235}$ Indeed, some (including one of us) have suggested going even further: returning to the days of central claiming. ${ }^{236}$ Doing so wouldn't necessarily reduce the market power of particular inventions; how much control a patent gave its owner over a market would depend on the latitude the courts gave any given patentee to sue accused infringers who sold substitutes with somewhat different characteristics. But limiting functional claiming would at least require courts to think consciously about the breadth of a patent owner's control rather than subordinating it to an exercise in the interpretation of documents.

The control that patentees have over markets is also a function of a power that patents confer that copyrights and trade secrets don't: the power to prevent independent development. The power of a copyright is limited by the ability of others working independently to develop their own works, even if those works are similar in significant respects to the copyrighted work. Patents, by contrast, give the patentee control over product space whether or not the defendant copied from the patentee. Indeed, patents today are overwhelmingly asserted, not against accused copyists but against independent developers. ${ }^{237}$ Some have suggested that patent law, like copyright, should limit its reach to those who obtain the idea from the patentee. ${ }^{238}$ That may or may not be a good idea. ${ }^{239}$ But

233. See 35 U.S.C. $\$ 112$ (2006).

234. See Mark A. Lemley, The Return of Functional Claiming (working paper 2012) (on file with author); Mark A. Lemley, David W. O'Brien \& Wade Malone, Capability Claiming (Feb. 2012) (unpublished presentation) (making this argument), available at https://www.law.stanford.edu/display/ images/dynamic/events_media/Panel\%201\%20-\%20Mark\%20Lemley,\%20et\%20al\%20-\%20Capability\% 20Claiming.pdf.

235. See Oskar Liivak, Rescuing the Invention from the Cult of the Claim, 42 Seton Hall L. Rev. 1 (2012) (arguing that modern practice illegitimately allows patentees to claim far beyond what they have invented).

236. See, e.g., Dan L. Burk \& Mark A. Lemley, Fence Posts or Sign Posts? Rethinking Patent Claim Construction, 157 U. PA. L. Rev. 1743 (2009).

237. Christopher A. Cotropia \& Mark A. Lemley, Copying in Patent Law, 87 N.C. L. Rev. 1421 (2009).

238. Stephen M. Maurer \& Suzanne Scotchmer, The Independent Invention Defense in Intellectual Property, 69 Economica 535 (2002); Carl Shapiro, Prior User Rights, 96 Am. Econ. Rev. 92 (2006); Samson Vermont, Independent Invention as a Defense to Patent Infringement, 105 Mich. L. Rev. 475 (2006).

239. For discussion and some skepticism, see Mark A. Lemley, Should Patent Infringement Require Proof of Copying?, 105 Mich. L. Rev. 1525 (2007). 
if adopted, it would substantially reduce the number of cases in which patents conferred market power by allowing an important source of substitutes.

\section{EXPERIMENTAL USE AND REVERSE ENGINEERING}

Looking at the issue of substitutes more dynamically, courts might make more room for parties to design around patented inventions or copyrighted works by enabling greater access to and experimentation with those inventions and works. In the patent context, this would primarily take the form of a much-expanded experimental use doctrine, which the Federal Circuit now interprets quite narrowly. Under the Madey v. Duke University standard, ${ }^{240}$ "so long as the act is in furtherance of the alleged infringer's legitimate business and is not solely for amusement, to satisfy idle curiosity, or for strictly philosophical inquiry, the act does not qualify for the very narrow and strictly limited experimental use defense."241 And in Madey, the Federal Circuit interpreted those disqualifying business interests very broadly, noting that even research at nonprofit universities is usually not experimental use because, while those universities "often sanction and fund research projects with arguably no commercial application whatsoever," the projects "unmistakably further the institution's legitimate business objectives." 242 Among other things, the projects further the objectives of "educating and enlightening students and faculty participating in these projects" and of "increas[ing] the status of the institution and lure lucrative research grants, students and faculty." 243

Because in many cases experimenting with a patented invention may be necessary in order to learn how it works so that substitutes might be created, the current doctrine does not enable as much competitive entry as it might. A revised doctrine that insulated otherwise infringing activity that is necessary to the ultimate development of a noninfringing substitute-in other words, making or using an invention in the research and development phase of a new invention rather than making consumptive use of a research tool ${ }^{244}$ — would do a better job of enabling entry of substitutes. As a practical matter, however, experimental use may occur even in the absence of a legal right, simply because infringement that occurs only in a laboratory is hard to detect.

Something similar could be said in the copyright context. The Digital Millennium Copyright Act ("DMCA") 245 prohibits the circumvention of copy restric-

240. 307 F.3d 1351, 1352 (Fed. Cir. 2002).

241. Id. at 1362 .

242. Id.

243. Id. There is a separate, statutory experimental use exemption for developing information to be submitted to the Food and Drug Administration in connection with a generic drug application, 35 U.S.C. § 271(e)(1) (2006), but it is quite narrow. See Merck KGaA v. Integra Life Sciences I, Ltd., 545 U.S. 193, 206-07 (2005).

244. For more on this distinction and its importance, see, for example, Rebecca S. Eisenberg, Patents and the Progress of Science: Exclusive Rights and Experimental Use, 56 U. CHI. L. Rev. 1017 (1989).

245. 17 U.S.C. $§ 1201$ (2006). 
tions even where the purpose of that circumvention is to make a use of a protected work that is not itself illegal. Although the statute does exempt certain circumvention done for the purposes of achieving interoperability, ${ }^{246}$ interoperable products may often be complements to, rather than substitutes for, the copyrighted work protected by the technological measures. Thus, a broader exemption that enabled circumvention for the purpose of reverse engineering to develop a noninfringing but competitive work might promote market substitutes. ${ }^{247}$ The point here, just as in the patent context, is to free those who might create closer substitutes for the relevant invention or work of authorship to engage in the activities necessary to the creation of such a substitute.

\section{E. EXHAUSTION AND THE FIRST SALE DOCTRINE}

Finally, one set of doctrines crosses all doctrinal boundaries. Going by the name "exhaustion" or "first sale," copyright, patent, and trademark all impose limits on the ability of IP rightsholders to control what happens to particular copies of their goods once they have sold those goods into the open market.

Section 109 of the Copyright Act, for instance, gives owners of lawfully made copies the right to distribute those copies, even though distribution would otherwise violate one of the copyright owner's exclusive rights. ${ }^{248}$ Trademark law too recognizes the right of legitimate owners of branded goods to resell, and even to advertise the resale of, those goods. ${ }^{249}$ And patent law treats exhaustion of rights upon first sale as a fundamental limitation on the scope of the patent. $^{250}$

The first-sale or exhaustion doctrine is a powerful tool for reducing the market power of an IP owner by enabling better substitutes. Used copies of the original work are likely in many cases to be much better substitutes than other works even in the same genre would be. The Tesla Roadster may be in a class by itself, but it still faces competition from used Tesla Roadsters.

Antitrust law has long acknowledged this fact, and a number of antitrust cases depend on the ability of fringe competitors to offer used or reconditioned goods originally manufactured by a company that would otherwise hold unre-

246. Id. § 1201(f)(1) (exempting circumvention done "for the sole purpose of identifying and analyzing those elements of the program that are necessary to achieve interoperability of an independently created computer program with other programs, and that have not previously been readily available to the person engaging in the circumvention").

247. Cf. Pamela Samuelson \& Suzanne Scotchmer, The Law and Economics of Reverse Engineering, 111 YALE L.J. 1575, 1637-38 \& n.304 (2002) (arguing that individual acts of circumvention and private tool-making incidental to such circumventions should be exempted under the DMCA but noting that "this does not mean that an individual act of circumvention should exempt the circumventor from liability if it results in copyright infringement"). Dan Burk has argued that using the anticircumvention provisions to block the creation of lawful, noninfringing works is a form of misuse. Dan L. Burk, Anticircumvention Misuse, 50 UCLA L. Rev. 1095 (2003).

248. 17 U.S.C. $§ 109$ (a) (2006).

249. Champion Spark Plug Co. v. Sanders, 331 U.S. 125, 128-30 (1947); see also Nitro Leisure Prods., L.L.C. v. Acushnet Co., 341 F.3d 1356, 1362-63 (Fed. Cir. 2003).

250. Quanta Computer, Inc. v. LG Elecs., Inc., 553 U.S. 617, 628-29 (2008). 
strained market power. ${ }^{251}$ That is true even if the goods are protected by IP rights because all IP doctrines have some sort of first-sale or exhaustion principle limiting control of resales.

The first-sale doctrine, however, is under sustained attack in each area of law. In copyright, that is in part a function of the Internet; the principle that one owns a particular copy and can pass it along to others is harder to apply when virtually anything one does involves the making of new copies. ${ }^{252}$ But in larger part, it results from the growth of shrinkwrap, clickwrap, and browsewrap licenses and judicial deference to those "contracts." ${ }^{253}$ IP owners have increasingly sought either to prevent the resale of their goods altogether or to condition the price at which those goods can be resold. ${ }^{254}$

Trademark courts, too, are nearly always equivocal about this "right" to resell branded products in that they universally express that right as subject to the requirement that the use not cause confusion. ${ }^{255}$ And the Ninth Circuit has even held that the first-sale doctrine can be trumped by initial interest confusion, at least where the defendant sells a product into which the trademark is incorporated, as opposed to cases where the branded product itself is resold without modification. $^{256}$

The first-sale doctrine provides an important limitation on the power an IP right confers. Efforts to undermine the doctrine threaten to confer substantial additional market power on IP owners by constraining the closest source of substitutes. Giving IP owners that power might conceivably make sense if we had reason to think IP rights today were significantly weaker than they should

251. Cf. United States v. Aluminum Co. of Am. (Alcoa), 148 F.2d 416 (2d Cir. 1945) (excluding secondary aluminum from the market for virgin aluminum). The leading antitrust treatise says this result "rests on doubtful premises" and explains that once Alcoa has sold virgin aluminum, it loses control over what buyers do with the aluminum, so it may face competition from that aluminum in a secondary sale. 2B AREEDA \& HovenKAMP, supra note 107, II 573a.

252. See Mark A. Lemley, Dealing with Overlapping Copyrights on the Internet, 22 U. DAYTON L. Rev. 547 (1997); Aaron Perzanowski \& Jason Schultz, Copyright Exhaustion and the Personal Use Dilemma, 96 Minn. L. Rev. (forthcoming 2012); R. Anthony Reese, The Public Display Right: The Copyright Act's Neglected Solution to the Controversy Over RAM “Copies,” 2001 U. ILL. L. Rev. 83.

253. See, e.g., Vernor v. Autodesk, Inc., 621 F.3d 1102 (9th Cir. 2010) (finding customer to be a licensee, not an owner); ProCD, Inc. v. Zeidenberg, 86 F.3d 1447 (7th Cir. 1996) (enforcing shrinkwrap license terms). For discussion, see, for example, Nancy S. Kim, The Software Licensing Dilemma, 2008 B.Y.U. L. Rev. 1103; Mark A. Lemley, Terms of Use, 91 Minn. L. Rev. 459 (2006).

254. See Mallinckrodt, Inc. v. Medipart, Inc., 976 F.2d 700 (Fed. Cir. 1992) (finding that violation of a prohibition on reuse could constitute patent infringement); $c f$. UMG Recordings, Inc. v. Augusto, 628 F.3d 1175 (9th Cir. 2011) (attempting-unsuccessfully-to control resale of promotional copies of CDs). Antitrust law, which used to make it illegal per se to set the resale price even of a good protected by an IP right, see Dr. Miles Med. Co. v. John D. Park \& Sons Co., 220 U.S. 373 (1911), recently relaxed its scrutiny of such agreements, opening the door to more such efforts. See Leegin Creative Leather Prods., Inc. v. PSKS, Inc., 551 U.S. 877 (2007) (overruling Dr. Miles and applying the rule of reason to vertical price restraints).

255. Champion Spark Plug Co. v. Sanders, 331 U.S. 125, 130 (1947); Au-Tomotive Gold Inc. v. Volkswagen of Am., Inc., 457 F.3d 1062 (9th Cir. 2006); Nitro Leisure Prods. L.L.C. v. Acushnet Co., 341 F.3d 1356, 1362-63 (Fed. Cir. 2003).

256. Au-tomotive Gold, 457 F.3d at 1076. 
be. But there is no such consensus, and we find it troubling that IP owners can decide for themselves that the law should give them significant additional power merely by rewriting a standard-form contract to which everyone "agrees" without reading merely by visiting a web site.

Similarly, if the goal is to reduce differentiation, we should want few limitations on parties' ability to resell (or to rent or otherwise recirculate) both patented and branded goods. For it will often be the case, in our view, that second-hand or used goods will be better substitutes for branded goods than functionally interchangeable goods sold under other brands. Indeed, to the extent the differentiation is a function of brand meaning, resold goods will naturally and legitimately share in that meaning.

\section{CONCLUSION}

Courts in a variety of IP contexts engage more or less explicitly in market definition as a predicate to some doctrinal determination. They do this, however, without any apparent methodology, which has the pernicious effect of making market definition simply a tool for reaching desired results. Antitrust law has a well-developed methodology for defining markets, but, as we argued, that methodology does not work well in the context of IP goods. Specifically, antitrust's traditional approach is based on a classical conception of competition in which parties sell largely undifferentiated goods and compete only on price or quality. IP goods, however, differ precisely because they are differentiated; indeed, that is largely the point of IP rights- to enable owners to prevent others from copying too closely so that the IP owners can reap a profit sufficient to provide incentives to invent or distribute (or, in the case of trademarks, to enable consumers to differentiate between goods of different source).

Traditional market definition is too rigid to accommodate this reality because it asks whether particular goods are in or out of the market rather than focusing, as we would, on the closeness of available substitutes, taking into account the inevitability of some differentiation. In other words, in a market full of imperfect substitutes, it makes more sense to ask just how imperfect the substitutes are. To the extent we want to reduce IP owners' market power, there are doctrinal levers within IP that can be used to enable more and better substitutes. 